\title{
Inventory of Forest Attributes to Support the Integration of Non-provisioning Ecosystem Services and Biodiversity into Forest Planning-from Collecting Data to Providing Information
}

\author{
Thomas Knoke $^{1} \cdot$ Mengistie Kindu $^{1} \cdot$ Thomas Schneider $^{1} \cdot$ Terje Gobakken $^{2}$
}

Accepted: 14 January 2021

(C) The Author(s) 2021, corrected publication 2021

\begin{abstract}
Purpose of Review Our review provides an overview of forest attributes measurable by forest inventory that may support the integration of non-provisioning ecosystem services (ES) and biodiversity into forest planning. The review identifies appropriate forest attributes to quantify the opportunity for recreation, biodiversity promotion and carbon storage, and describes new criteria that future forest inventories may include. As a source of information, we analyse recent papers on forest inventory and ES to show if and how they address these criteria. We further discuss how mapping ES could benefit from such new criteria and conclude with three case studies illustrating the importance of selected criteria delivered by forest inventory.

Recent Findings Recent studies on forest inventory focus mainly on carbon storage and biodiversity promotion, while very few studies address the opportunity of recreation. Field sampling still dominates the data collection, despite the fact that airborne laser scanning (ALS) has much improved the precision of large-scale estimates of the level of forest ES provision. However, recent inventory studies have hardly addressed criteria such as visible distance in stands, presence of open water bodies and soil damages (important for the opportunity of recreation) and naturalness (here understood as the similarity of the forest to its natural state) and habitat trees and natural clearings (important for biodiversity promotion). The problem of quantifying carbon stock changes with appropriate precision has not been addressed. In addition, the reviewed studies have hardly explored the potential of inventory information to support mapping of the demand for ES.

Summary We identify challenges with estimating a number of criteria associated with rare events, relevant for both the opportunity of recreation and biodiversity promotion. These include deadwood, rare species and habitat trees. Such rare events require innovative inventory technology, such as point-transect sampling or ALS. The ALS technology needs relatively open canopies, to achieve reliable estimates for deadwood or understorey vegetation. For the opportunity of recreation, the diversity among forest stands (possibly quantified by geoinformatics) and information on the presence of open water bodies (provided by RADAR, ALS data or use of existing maps) may be important. Naturalness is a crucial criterion for native biodiversity promotion but hard to quantify and assess until now. Tree species identification would be crucial for this criterion, which is still a challenge for remote sensing techniques. Estimating carbon storage may build on biomass estimates from terrestrial samples or on remotely sensed data, but major problems exist with the precision of estimates for carbon stock changes. Recent approaches for mapping the
\end{abstract}

This article is part of the Topical Collection on Forest Management

Thomas Knoke

knoke@tum.de

1 Institute of Forest Management, TUM School of Life Sciences

Weihenstephan, Life Science Systems, Technische Universität

München, Hans-Carl-von-Carlowitz-Platz 2,

85354 Freising, Germany

2 Faculty of Environmental Sciences and Natural Resource Management, Norwegian University of Life Sciences, Ås, Norway 
supply side of forest ES are promising, while providing so far uncommon structural information by revised inventory concepts could be helpful also for mapping the demand for ES. We conclude that future studies must find holistic inventory management systems to couple various inventory technologies in support of the integration of nonprovisioning ES and biodiversity into forest planning.

Keywords Forest's contributions to societal needs $\cdot$ Ecosystem service criteria $\cdot$ Recreation $\cdot$ Biodiversity $\cdot$ Carbon storage $\cdot$ Inventory techniques $\cdot$ Mapping of ecosystem services

\section{Introduction}

The sustainable management of forests is important to meet current needs for forest products and services and also to maintain or expand the capacity of forests to meet the needs of future generations [1]. In this context, "forest management" concerns all activities necessary to produce a continuous flow of desired forest goods and services, while accounting for the forest's intangible values [2]. The integration of nonprovisioning ecosystem services (ES) and biodiversity into forest planning may address these intangible values and thus enhance the contribution of forests to a good life for people [3]. However, accounting for non-provisioning ES $[4,5]$ in forest planning and optimization, such as recreation and carbon sequestration, but also the conservation of forest biodiversity, is uncommon up to now. This demanding task requires appropriate data and information about the forests' actual condition and development.

Forest inventories provide a crucial source of information for forest planning [6] and may offer information about criteria and indicators to assess the forest status, sustainable management and its provision of goods and services [7]. The term forest inventory means both an information catalogue and the process of measuring and evaluating the data from which the inventory draws the information [8]. While the data merely represent observable properties, the information is usable, processed data [9]. To illustrate, when decision-makers ask questions starting with "what ...", "how much ..." or "where ...", an inventory may provide information to answer these questions based on processed data. Therefore, the need for an inventory to provide appropriate information for integrating ES and biodiversity into forest planning is acute.

In our review, we focus on new inventory criteria to provide information concerning the integration of nonprovisioning ES and biodiversity into forest management planning, which we qualitatively derive from published analyses of stakeholder preferences. A qualitative analysis of such criteria was necessary, as our quantitative review of forest inventory studies published from 2015 to 2019 (see below) was not successful in revealing sufficient information on criteria preferred by stakeholders. For the same reason, we complemented the results of our general search with specific searches for the inventory of single criteria. We discovered a gap in the availability of specific inventory criteria to improve the inclusion of non-provisioning ES into forest planning. Our objective is thus to provide an overview on new inventory criteria and on recent studies dealing with the inventory of such criteria. On this basis, we derive a roadmap for future inventory-related forest research.

Our review begins with specific forest attributes which stakeholders preferred in choice experiments or which other studies recommended as suitable indicators (from here onwards called attributes or criteria) concerning our nonprovisioning ES and biodiversity-related management objectives. The review derives forest attributes associated with recreation, promotion of biodiversity and conservation as well as carbon storage. We identify currently uncommon attributes, not covered by classical timber-based inventories, and formulate new criteria to elucidate what future forest inventories may include to support considering ES and biodiversity in forest planning. We then analyse recent papers on forest inventory and ES in light of these criteria to show if and how these papers quantify them. This part focuses on techniques to answer the question of how much forests may contribute to these criteria. The paper continues with mapping topics, addressing where forests provide the ES of interest and how forest inventory may help inform about the demand for the analysed ES. We conclude our paper by providing three case studies illustrating the importance of selected criteria for forest-related decision-making.

\section{Selected ES Categories and Reviewed Studies}

The annual output of scientific papers dealing with ES is enormous and continues to grow (Fig. 1). We systematically reviewed studies included in Elsevier's database SCOPUS published from 2015-2019, which mention ES and forest and inventory in their title, abstract and keywords. Their number is much smaller than the number of studies dealing with ES. However, despite their relatively small number, we counted 39 different forest-related ES covered by these studies. For a better focus, we concentrated our paper on three categories through which forests contribute to a good life for people: (1) providing opportunities for recreation, (2) biodiversity promotion and conservation and (3) carbon storage.

We selected (2) and (3) because the systematically reviewed studies addressed these categories most frequently. 
Fig. 1 Frequency of studies addressing a ecosystem services (ES) or $\mathbf{b}$ ES and forest, ES and inventory or ES and forest and inventory. Search categories focused on article title, abstract and keywords for studies listed in the Elsevier database Scopus (https://www.scopus.com). Search carried out for period 2015-2019 up to the date 31.12. 2019

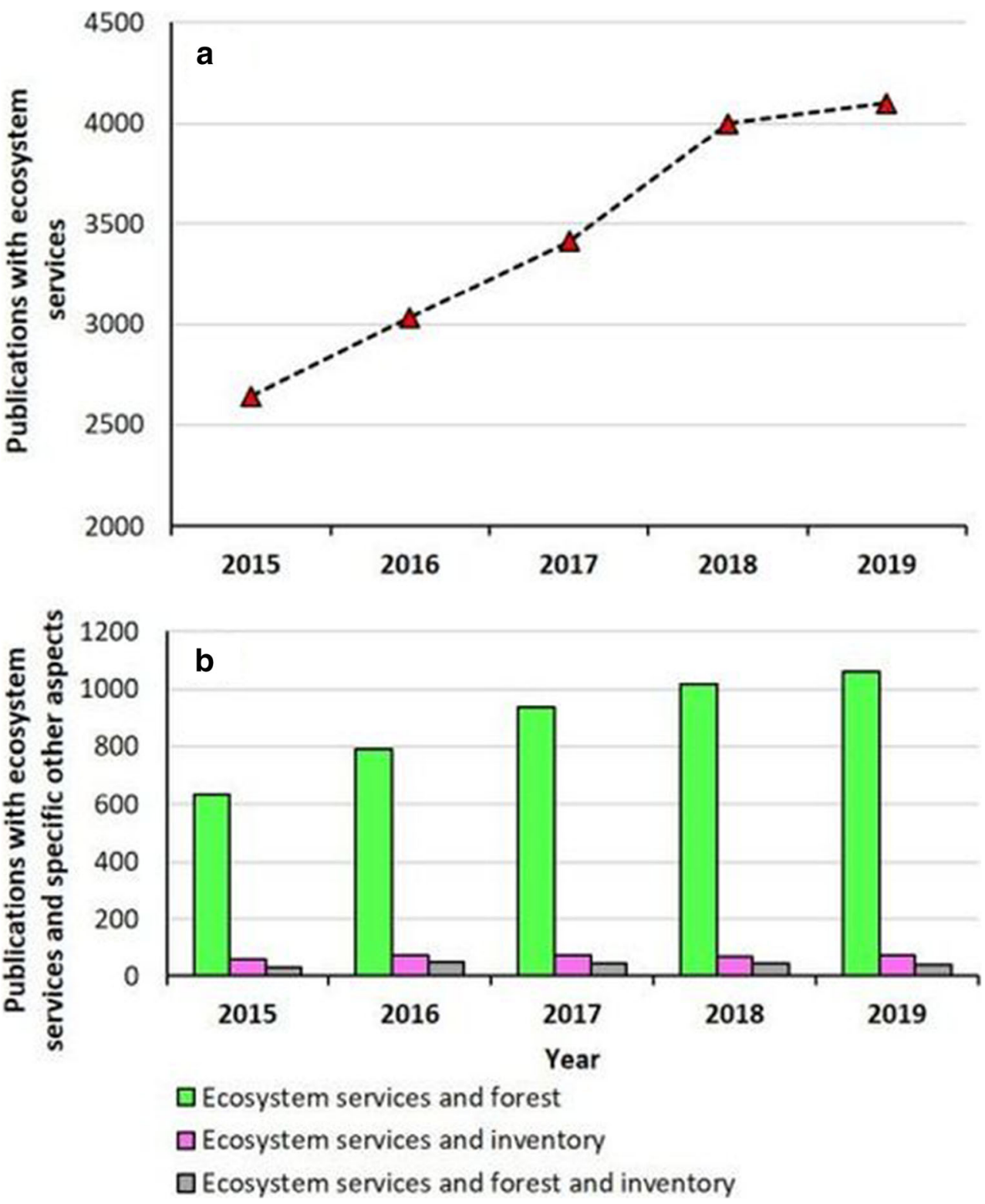

While providing the opportunity for recreation was not often addressed in our set of reviewed studies, a recent review has shown a large willingness to pay for the opportunity of recreation [10] so we may assume a high demand for the opportunity of recreational activities. Concerning this ES, we refer to "characteristics of living systems that enable activities promoting health, recuperation or enjoyment through passive or observational interactions" [11]. We also consider the conservation of biodiversity as an important contribution to a good life for people. With biodiversity, we refer to the "... variability among living organisms ...", including “ ... diversity within species, between species and between ecosystems" [12]. The apparent high willingness to pay for biodiversity promotion and conservation [10] shows that people obtain satisfaction from enjoying the presence, diversity and abundance of organisms or ecosystems [13]. For example, Martínez-
Jauregui et al. [14] and Fraser et al. [15] confirmed the large social and cultural value people associate with biodiversity indicators. Biodiversity can bring indirect [13] and direct value to people [3]; hence, the importance of its integration into forest planning is evident. The ES of carbon storage refers to a contribution of forests to the "regulation of chemical composition of atmosphere ..." [11]. Carbon storage is an important topic [16] that often requires much consideration in forestrelated decision-making [17].

In addition to our systematic review, we carried out qualitative searches. Using Google Scholar, for example based on the word combination "choice experiment forest biodiversity", we selected studies to provide us with qualitative information on forest criteria useful to consider biodiversity conservation in forest planning. From the range of possible criteria, we concentrated on criteria not commonly seen so 
far in our review of recent studies, which are only partially included or totally absent from timber-based inventories. As detailed below, for the opportunity of recreation, we searched the systematically selected studies for criteria including the diversity among forest stands, tree spacing, forest edges, visible distance inside the forest stands, presence of open water bodies (e.g. lakes, rivers or streams) and soil damage. We associated deadwood and naturalness with the objective of native biodiversity promotion and conservation. Further criteria for the biodiversity objective are habitat for endemic species, natural ecological processes (set aside areas), large trees, habitat trees, rare species, natural clearings and biodiversity indices. For carbon storage, we focus on carbon content in living biomass, carbon in dead organic matter and carbon in soils.

Our review excluded timber production as well as nontimber forest products, such as wild berries. Comprehensive reviews of wild edible fruits and their inventory exist [18-20] and various articles have studied the integration of wild berry yield in forest planning and optimization [21-23]. In addition, we refer the reader to Andrew et al. [24•], Galbraith et al. [25•] or Vargas et al. [26] for more details with regards to remotely sensed ES. Concerning the ways which components of the ES cascade [27] have been analysed in recent studies, we recommend Boerema et al. [28].

\section{Criteria Not Commonly Found in Current Timber-Based Forest Inventories}

Inventories must provide input information for specific planning or decision criteria, which quantify how the forest has the potential to contribute to the objectives of decision-makers. The decision criteria depend on decision-makers' preferences, which are variable [29] and depend, for example on the spatial scale of decision-making (Table 1). Based on information on decision criteria, decision variables and optimisation algorithms, planning tools may inform forest-related decisionmaking [42]. While decision criteria have classically focused on timber production and economic profit, today they include additional criteria. For example, various previously uncommon forest attributes are now relevant for specific ES and biodiversity promotion (Table 2). At the national level, attributes such as the proportion of broadleaves and forest with a composition similar to the natural vegetation or the changes in carbon storage in forests are important decision criteria for government programs and related forest policies. The availability of timber resources will be a decision criterion to establish new capacities in the timber industry.

While decision criteria depend on stakeholder preferences, decision variables are controllable by decision-makers. Studies on forest-related management planning may differ in their decision variables, as we will show with our case studies at the end of the paper. Forest management requires information for spatial scales from local to regional, from plot to stand to enterprise levels and the relevant decision variables will differ depending on the scale considered.

For example, at the forest stand and enterprise levels, the decision variables include (a) when to harvest a tree or stand; (b) the number or volume or area of remaining and harvested trees per size or age class and (c) the long-term tree species or stand-type composition of the forest enterprise. These decision variables remain relatively robust over time, because a limited number of silvicultural operations are basic actions suitable to control the development of a forest. Such operations include harvesting or leaving aside stands or trees and establishing new forest by natural regeneration, planting or sowing (Table 1).

Clearly, good planning decisions need more information than inventories can provide. A considerable part of the decision criteria listed in Table 1 depends on models, socioeconomic information and assessment of uncertainty, coupled with inventory information to support good decisions. However, inventory information is indispensable to characterise the actual and past forest status, without which decisionmakers may never derive optimal strategies to meet their objectives. Inventory information can also be a base for projection and monitoring, as a means of validating the development of decision criteria over time.

Our qualitative searches provided us with a range of possible forest attributes associated with our non-provisioning ES and biodiversity, which scientists have investigated in various papers (Table 2) [31-35, 37, 38, 41, 43]. For example, Giergiczny et al. [33] published results of a detailed choice experiment, showing that the Polish public preferred irregularly structured, multiple tree species stands of higher age (see Table 2 for more detailed attributes). Polish people also appreciated variability among forest stand types alongside the preferred hiking roads or paths. However, for deadwood and the presence or absence of an understorey vegetation, people showed inverted $U$-shaped preferences, meaning that they preferred medium levels of these attributes. Based on recreational preferences surveyed during the 1990s in Sweden and Denmark, Eggers et al. [32] developed a recreation index with negative coefficients for deadwood, harvest residues and soil damage. Similar to the preferences modelled for deadwood in [32], the results of a study focusing on the Alpine region have shown that naturalness influenced the frequency of recreation activities rather negatively [35]. Improving the opportunities for recreation may thus form a trade-off with the objective of biodiversity promotion and conservation, where natural processes and deadwood are generally preferred attributes [38]. Only in a choice experiment with German participants by Meyerhoff et al. [37], carried out in 2004, respondents ranked deadwood for biodiversity conservation as having low importance. For carbon storage, the decision-makers' preferences 
Table 1 Possible decision variables and decision criteria. We have compiled this Table drawing on the authors' research experiences, to provide background for our review

\begin{tabular}{|c|c|c|c|}
\hline \multirow[t]{2}{*}{ Spatial level } & \multirow[t]{2}{*}{ Decision variables (examples) } & \multicolumn{2}{|l|}{ Decision criteria (examples) } \\
\hline & & For timber production & For ES and biodiversity, further detailed in Table 2 \\
\hline Tree & When to harvest, if at all? & $\begin{array}{l}\text { Vigour, stability, quality, net } \\
\text { present value, size }\end{array}$ & $\begin{array}{l}\text { Habitat/deadwood quality to inform about } \\
\text { biodiversity promotion and conservation }\end{array}$ \\
\hline Stand & $\begin{array}{l}\text { How much timber (or area) of which tree species, } \\
\text { when to harvest, rotation period, how to } \\
\text { establish new forest? } \\
\text { How much standing/lying deadwood to have? } \\
\text { How much large trees to have? }\end{array}$ & $\begin{array}{l}\text { Growth rate, stability, quality, } \\
\text { net present value, economic } \\
\text { utility }\end{array}$ & $\begin{array}{l}\text { Biomass data to inform about carbon storage; } \\
\text { amount of standing and lying deadwood; } \\
\text { variability/diversity data to inform about } \\
\text { biodiversity promotion and conservation; } \\
\text { number of large trees }\end{array}$ \\
\hline \multirow[t]{3}{*}{$\begin{array}{l}\text { Forest } \\
\text { (enter- } \\
\text { prise) }\end{array}$} & $\begin{array}{l}\text { How much area to allocate to which stand types? } \\
\text { What is the spatial configuration? }\end{array}$ & $\begin{array}{l}\text { Growth performance, } \\
\text { diversification, net present } \\
\text { value, economic utility }\end{array}$ & \multirow{5}{*}{$\begin{array}{l}\text { Infrastructural criteria, variability among forest } \\
\text { stands, naturalness criteria to inform about } \\
\text { recreation opportunities; variability/diversity } \\
\text { data; patchiness, fragmentation; data on carbon } \\
\text { stock changes; revenues for additional carbon } \\
\text { stored; costs of sampling }\end{array}$} \\
\hline & $\begin{array}{l}\text { When to harvest how much timber and where? } \\
\text { How much area to set aside? }\end{array}$ & $\begin{array}{l}\text { Standing timber stock, timber } \\
\text { growth, economic profit, } \\
\text { minimum opportunity costs }\end{array}$ & \\
\hline & $\begin{array}{l}\text { How large should the standard error of an } \\
\text { inventory be? }\end{array}$ & $\begin{array}{l}\text { Costs of sampling and } \\
\text { opportunity costs of poor } \\
\text { decisions }\end{array}$ & \\
\hline Landscape & $\begin{array}{l}\text { What is the percentage of land to allocate to which } \\
\text { land-use/land-cover type? What is the size and } \\
\text { number of forest and agricultural parcels? }\end{array}$ & $\begin{array}{l}\text { Contribution of the forest to } \\
\text { economic profit and } \\
\text { economic risk mitigation }\end{array}$ & \\
\hline $\begin{array}{l}\text { Other levels } \\
\text { (e.g. } \\
\text { national } \\
\text { or global) }\end{array}$ & $\begin{array}{l}\text { How to allocate subsidies? Which political } \\
\text { programs to develop? How large shall the } \\
\text { investments into the timber industry be? }\end{array}$ & $\begin{array}{l}\text { Tree species, standing timber } \\
\text { stock, timber growth, } \\
\text { expected timber flows for the } \\
\text { wood industry }\end{array}$ & \\
\hline
\end{tabular}

are less controversial. Here, measuring the carbon content in above- and belowground, living and dead biomass and particularly quantifying the carbon stock changes precisely enough is important [41]. The conventional timber-related forest inventories will provide already valuable information for this ES. Table 2 shows a summary of common and previously uncommon criteria to support integrating ES and biodiversity into forest planning.

\section{How to Quantify Previously Uncommon Forest Criteria}

The set of systematically reviewed studies comprised of only nine studies dealing with the opportunity of recreation. While Delgado-Aguilar et al. [44] analysed hunting and tourism in the tropics, other studies were less specific about the activities associated with recreation [36, 43, 45-47]. Biodiversity promotion and conservation were topics in 54 studies. With 74 papers on forest carbon storage, the reviewed papers most frequently addressed this ES (Fig. 2). However, while carrying out the systematic review, we observed that a couple of important studies were missing. We thus complemented our review by further in-depth searches on alternative methods to quantify the identified forest criteria, using Google Scholar.
We have listed the additional studies in Table 3, third column, which provide only examples, subjectively selected based on the expertise of the authors.

For the opportunity of recreation, people may consider built infrastructure as very important [109]. We must be aware that the current forest attributes are sometimes less important than infrastructural aspects. However, there still appears to be potential for improvement of the forest structure, given the documented preferences of visitors (Table 3). For example, the diversity among forest stand types is an important attribute, being of particular importance alongside forest roads and hiking paths. GIS evaluation may build on delineated stand types and help assess this criterion, for example based on an adapted Shannon diversity which is until now mostly used for assessing landscape diversity [48]. Field samples can deliver information on tree density (given enough samples per stand), while the presence/absence of understory may require field inspection or, as remote sensing alternative, airborne laser scanning (ALS) data analysis. In addition, national forest inventory information may support assessing the forest's attractiveness for recreation $[110,111]$. Forest edges mapped in plots will deliver the total length (and types) of forest edges [50]. Information on soil damage is uncommon at this point, but terrestrial plots may deliver such information when appropriately designed [56]. RADAR remote sensing may provide 


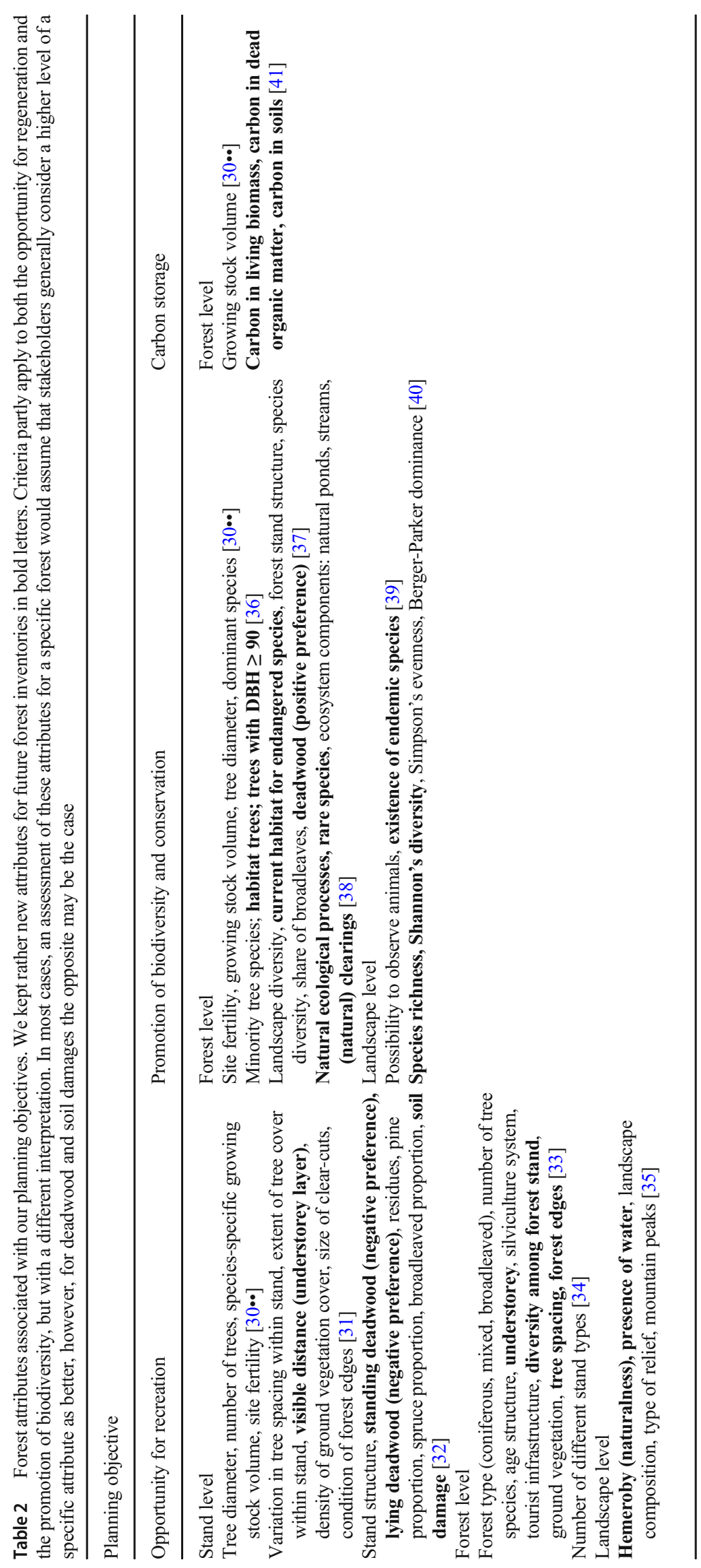



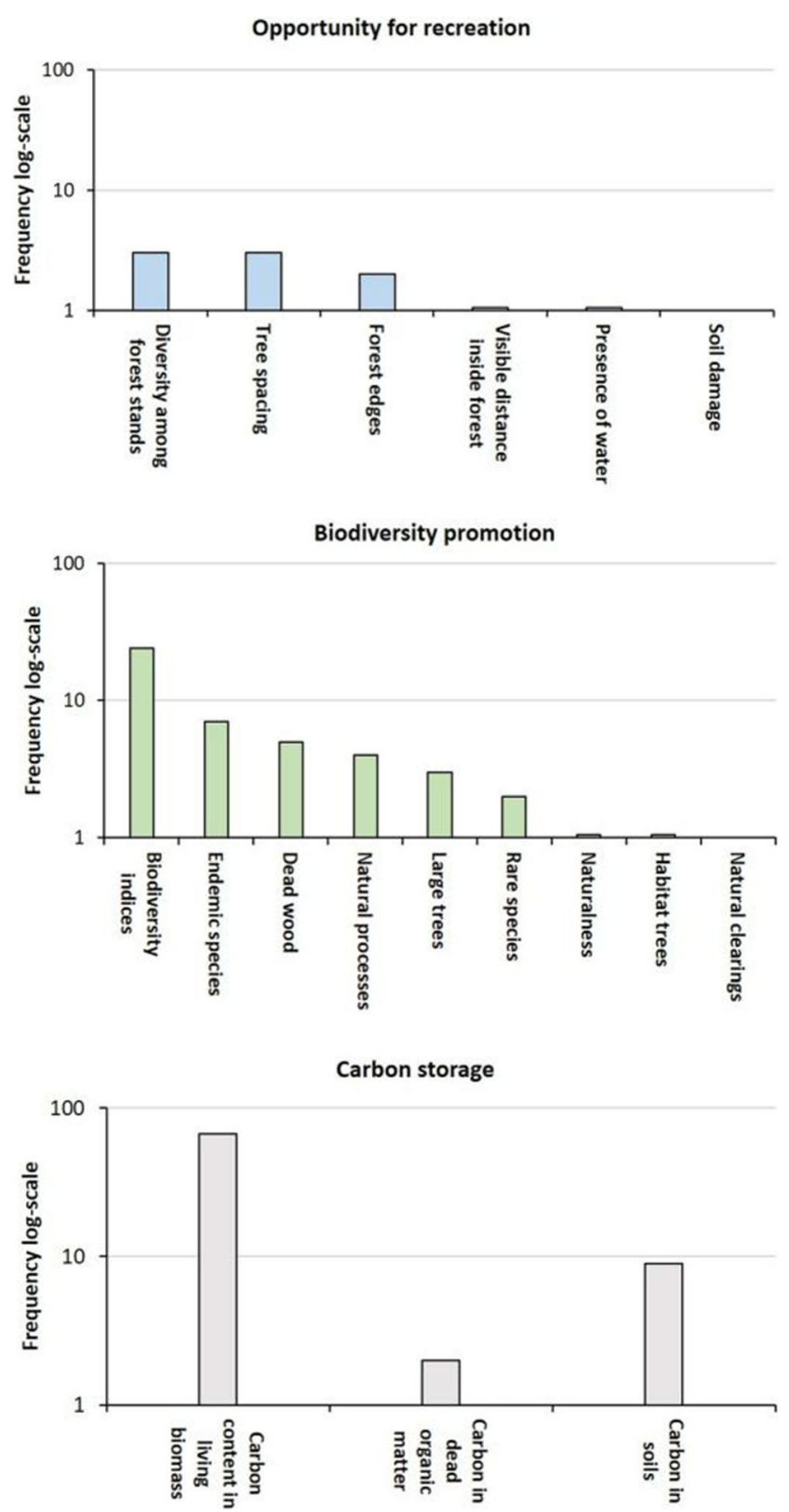

Fig. 2 Distribution of possible and previously uncommon inventory criteria related to recreation opportunities, biodiversity promotion and conservation as well as carbon storage in the reviewed studies. Data based on 212 studies mentioning ES, forest and inventory in article title, abstract or keywords for studies listed in the Elsevier database Scopus (https://www.scopus.com). Search carried out for period 20152019 up to the date 31.12 .2019

information on the presence of open water bodies [54, 112], when information from existing maps is unavailable. Using ALS would be another alternative [55].

We found a substantial number of forest criteria to support biodiversity promotion and conservation, which are previously uncommon in timber-based forest inventories (Fig. 2, Table 3). Biodiversity indices are most popular among published criteria to measure biodiversity promotion and conservation. Classical inventory data may already inform these indices well quite often, e.g. tree species richness or Shannon's diversity, based on the proportions of recorded tree species and/or size classes. However, measuring rare events is still problematic, such as standing and downed deadwood, rare species, habitat trees or endemic species. The classical plot-based field sampling methods are not efficient in representing these criteria with appropriate precision, given limited inventory budgets. For rare events represented by standing trees, we would have intelligent terrestrial alternatives. For example, point-transect sampling is a very promising technique based on individual detection probabilities, suitable to collect data on still standing, but dead (or habitat or rare) trees [80]. This allows the recording of all events visible in the inventory, making representative results by computing and considering their inclusion probability post hoc (e.g. based on distance functions). Another innovative approach is a method building on "triangulation based inclusion probabilities" for a fixed number of trees [113]. For the case of downed deadwood, the classical line intersection technique is still the most efficient method [80,114]. Similar to the famous relascope technique with sampling proportional to tree size $[115,116]$, line intersect sampling considers individual inclusion probabilities for the elements to be sampled (e.g. depending on the angle between the sampling line and the downed deadwood log as well as the log's length).

Using ALS to detect downed deadwood [117] has made substantial progress, but successful detection requires relatively open canopies. The segmentation correctness would benefit from learning processes [118]. As another remote sensingbased alternative, Heurich et al. [51] have applied colourinfrared imagery to detect dead trees following bark beetle outbreaks in a National Park. Practical forest inventories have so far hardly absorbed such methods, neither the terrestrial nor the remote sensing-based techniques. The reviewed studies have not made use of them, but inventories supporting biodiversity promotion and conservation could achieve much higher efficiency when using such well-tailored designs. Finally, recording the naturalness of forests poses rather great challenges. Once we would have more clarity about the composition of a "perfectly" natural ecosystem [97], informative indices would help assess similarity [98] or hemeroby [119] (dissimilarity) of the existing forest compared to the natural forest.

For an assessment of naturalness, one would need the current tree species composition. Tree species identification is a persisting difficulty in applying remote sensing technology. Even if some remarkable progress is reported by using multi-spectral and hyperspectral imagery [83, 95, 120, 121] or building on ALS data combined with alpha shape metrics [122], tree species identification based on remote sensing data still poses a challenge. However, various authors have developed promising approaches to tackle the problems with the 
Table 3 Quantification methods for the identified criteria (examples). Alternative methods in the third column identified based on in-depth searches using Google Scholar

\begin{tabular}{|c|c|c|c|}
\hline & Criterion & Applied method in systematically reviewed studies & Alternative methods \\
\hline \multirow[t]{6}{*}{$\begin{array}{l}\text { Opportunity } \\
\quad \text { for } \\
\text { recreation }\end{array}$} & $\begin{array}{l}\text { Diversity among forest } \\
\text { stands }\end{array}$ & $\begin{array}{l}\text { Counting number of different forest stand types along a } \\
5 \text {-km trail through the forest }[31,43] \text { (field inspection } \\
\text { or maps) } \\
\text { Shannon's diversity over the whole forest [36] (maps) }\end{array}$ & $\begin{array}{l}\text { Shannon's compositional diversity [48] of stands } \\
\text { in buffer zones alongside forest roads (e.g. } \\
\text { GIS-based evaluation) }\end{array}$ \\
\hline & Tree spacing & Terrestrial inventory $[36,43]$ & Airborne laser scanning (ALS) [49] \\
\hline & Forest edges & - & $\begin{array}{l}\text { Sample plots, line intersect sampling [50]; } \\
\text { object-orientated image analysis based on } \\
\text { colour-infrared imagery [51]; } \\
\text { compartment-based inventory for forest edges } \\
\text { at stand level [52] }\end{array}$ \\
\hline & $\begin{array}{l}\text { Visible distance in a } \\
\text { forest stand (visual } \\
\text { penetration through } \\
\text { stand) }\end{array}$ & Stand density index [36] & $\begin{array}{l}\text { Presence of an understorey (yes/no) (field } \\
\text { inspection, laser scanning); understory volume } \\
\text { estimated by terrestrial laser scanning [53] }\end{array}$ \\
\hline & $\begin{array}{l}\text { Presence of open water } \\
\text { bodies }\end{array}$ & - & $\begin{array}{l}\text { RADAR images [54], ALS [55], topographic } \\
\text { maps, field inspection, use of existing maps }\end{array}$ \\
\hline & Soil damage & - & Vehicle tracks recorded in sample plots [56] \\
\hline \multirow{9}{*}{$\begin{array}{l}\text { Biodiversity } \\
\text { conservation } \\
\text { and } \\
\text { promotion }\end{array}$} & Biodiversity indices & $\begin{array}{l}\text { Mainly species richness, but also Shannon and various } \\
\text { similarity or dissimilarity indices }[15,36,45,46 \text {, } \\
57-74]\end{array}$ & \\
\hline & $\begin{array}{l}\text { Habitat for endemic } \\
\text { species }\end{array}$ & $\begin{array}{l}\text { Presence/absence of nesting platforms on sample trees } \\
\text { [75•], field sampling for native understory palms [76], } \\
\text { field-based mapping of silvo-pastoral systems } \\
\text { (Montados) [77], field samples analysed for } \\
\text { bryophyte and lichen indicators [78], field sampling } \\
\text { for deadwood, mean tree diameter, broadleaf } \\
\text { proportion [79] }\end{array}$ & $\begin{array}{l}\text { Point-transect sampling for trees with nesting } \\
\text { platforms, see habitat trees [80], estimation of } \\
\text { forest structural data with ALS [81], remotely } \\
\text { sensed data for tree species identification [82] } \\
\text { based on multi-temporal data [83]; forest field } \\
\text { inventories plus additional ecological } \\
\text { information gained during the inventory, and } \\
\text { aerial photographs used for habitat modelling } \\
\text { [84] }\end{array}$ \\
\hline & Deadwood & $\begin{array}{l}\text { Line intersect sampling [85], nested plots and } \\
\text { line-transect sampling [75•], forest ecosystem model } \\
\text { [71], spatial datasets and model [86] }\end{array}$ & $\begin{array}{l}\text { Point-transect sampling for standing deadwood } \\
\text { [80]; terrestrial laser scanning }[87,88] \\
\text { object-orientated image analysis based on } \\
\text { colour-infrared imagery [51] }\end{array}$ \\
\hline & $\begin{array}{l}\text { Natural ecological } \\
\text { processes (set aside } \\
\text { areas, protected areas) }\end{array}$ & $\begin{array}{l}\text { Participatory mapping in sacred agroforests and transect } \\
\text { sampling [15]; forest inventory plots combined with } \\
\text { IUCN red list criteria [89]; GIS, GPS and remote } \\
\text { sensing technology (3S) [90] }\end{array}$ & $\begin{array}{l}\text { Satellite-based remote sensing of natural } \\
\text { ecosystem processes, such as vegetation } \\
\text { phenology, primary production [91] }\end{array}$ \\
\hline & Naturalness & Photo-plots (on aerial photos) [92] & $\begin{array}{l}\text { Tree species identification supported by } \\
\text { hyperspectral [93, 94], multi-spectral [95] and } \\
\text { multi-temporal data [83]; characteristic species } \\
\text { identified by deep learning [96]; deviations } \\
\text { between the current state of a forest and a } \\
\text { reference state [97], evaluation, for example, } \\
\text { with stability index by Orwin and Wardle [98], } \\
\text { however, reference system (the natural state) } \\
\text { unclear. }\end{array}$ \\
\hline & Large trees & Field samples from national inventories $[36,61]$ & $\begin{array}{l}\text { ALS [99], very high-resolution satellite images } \\
\text { [96] }\end{array}$ \\
\hline & Rare species & $\begin{array}{l}\text { Field samples from national forest inventories [36], } \\
\text { drone-based mapping [100] }\end{array}$ & $\begin{array}{l}\text { Point-transect sampling [80], ALS data and } \\
\text { colour-infrared aerial imagery [101] }\end{array}$ \\
\hline & Habitat trees & Field samples from national forest inventories [36] & \\
\hline & Natural clearings & - & $\begin{array}{l}\text { Multi-seasonal high-resolution satellite imagery } \\
\text { [102]; high-resolution aerial orthophotos for } \\
\text { recent clearings caused by natural events [103] }\end{array}$ \\
\hline
\end{tabular}

Carbon storage Carbon content in living Field sampling for the living tree [57, 85, 104, 105] for biomass carbon storage and social costs of carbon [58]; global: Shuttle Radar Topography Mission (SRTM) to obtain rough estimates for vegetation height, which is 
Table 3 (continued)

\begin{tabular}{|c|c|c|}
\hline Criterion & Applied method in systematically reviewed studies & Alternative methods \\
\hline & $\begin{array}{l}\text { correlated with aboveground biomass (field samples) } \\
{[106] ; \text { local: biomass estimates based on ALS point }} \\
\text { clouds [30••]; tree carbon based on biomass estimates } \\
\text { and field samples; saplings and shrubs; herbs and } \\
\text { grasses [70] }\end{array}$ & \\
\hline $\begin{array}{l}\text { Carbon in dead organic } \\
\text { matter }\end{array}$ & $\begin{array}{l}\text { Field sampling for standing deadwood and coarse } \\
\text { woody debris, calculation based on decay factors or } \\
\text { wood density classes }[57,85,104] \text {, leaf litter }[70,105]\end{array}$ & $\begin{array}{l}\text { Object-oriented image analysis [51], collecting } \\
\text { and weighing coarse and fine woody debris as } \\
\text { well as litter from terrestrial sample plots [107] }\end{array}$ \\
\hline Carbon in soils & Various soil-subsamples per inventory plot $[57,70,105]$ & $\begin{array}{l}\text { Kumar et al. [108] used the normalised difference } \\
\text { vegetation index (NDVI) derived from satellite } \\
\text { imaginary and correlated with soil organic } \\
\text { carbon [108]; however, deviations at plot level } \\
\text { remained very high; soil profiles [107] }\end{array}$ \\
\hline
\end{tabular}

identification of tree species. For example, efficient algorithms using convolutional neural networks have become increasingly popular in forest inventory [96, 103, 123]. Such techniques build on deep learning techniques [124] and may, for instance, help delineate tree crowns [123] and allow identification of characteristic tree species [96]. We perceive the analysis of multi-seasonal observations of shifts in tree species' phenology as one promising approach to support the identification of tree species. The new generation of high temporal frequency systems may inform a multi-seasonal approach, facilitating the assessment of phenology and finally the identification of tree species (for example, based on systems such as RapidEye or Sentinel 2) [95, 125]. In combination with structural information via neighbourhood analysis and the option of height estimates, optical systems may provide a broad information basis for species assessment. However, even these approaches do not offer fingerprint-like identification accuracies, but merely estimations with a high probability of correct classification. Remote sensing builds on indirectly derived, diffuse information, but we may expect further advances from combining remote sensing methods, for example with physiological growth models and sitespecific information $[126,127]$.

Carbon stock estimates commonly build on terrestrial samples, established to quantify carbon in living biomass, dead organic matter and in soils (Table 3). For carbon, the assessment of stock changes is essential. Changes in the aboveground biomass, for example through forest degradation, contribute significantly to carbon stock changes. Soil organic matter may show constant values over long periods [128]. Dead organic matter is usually correlated with living aboveground biomass and positive changes may result mainly from increases in the forest area [107]. To obtain carbon stock estimates for larger areas, studies correlate terrestrial aboveground biomass [24•] or soil organic carbon recorded on sample plots [108, 129] with remotely sensed data. For very large areas, this approach may reveal good average estimates, while large deviations are common at the plot level $[108,130$, 131]. ALS facilitates the most precise yet expensive remote sensing-based estimates of aboveground carbon stocks. Vauhkonen [30••] showed how ALS data for a local scale study may improve predictions of the supply for several ES (including carbon storage). While dynamic growth models may support estimating prospective carbon stock changes [132], they may not deliver sufficiently reliable estimates of current carbon stock changes, which, for example carbon accounting would require. Insufficient precision of stock change estimates will continually be a challenge when stock changes are small [133], such as in private forest properties aiming to sell certified carbon credits at the voluntary carbon market.

Carbon stock changes are also important for assessing the climate impacts of forests and forestry at national or global levels. When appropriately harmonized and based on representative data, national forest inventories may provide such information at both the country and continental levels [134, 135]. However, at these scale levels, remote sensing would provide applicable methods fulfilling both the condition on large area coverage within a comparable period and on repetition frequency as required for global modelling purposes. Typical high-resolution systems for such tasks provide data at pixel resolutions between 5 and $30 \mathrm{~m}$. Examples include the Landsat series, Sentinel-2, Spot, Indian Remote Sensing Satellites (IRS) or RADAR systems. The RADAR systems include Sentinel 1, TerraSar X and TanDEM-X, Radarsat.

Recent studies gained progress in enhancing the precision of biomass estimates as a basis to quantify carbon stock changes. Promising examples for combining multiple remote sensing information sources to improve biomass estimation include Durante et al. [136, 137] and Næsset et al. [137••]. However, sampling at global scales based on data from 
satellites such as IceSat2 and GEDI may still suffer from errors increasing with dense canopy cover and steeper slopes [138]. Monitoring forest degradation processes, for example through the extraction of the economically most attractive tree species by selective logging, based on such systems is a challenge. This means that for the case of reducing forest degradation (REDD+ target), inventories dominated by remote sensing techniques may fail to deliver information at a precision high enough to quantify stock changes reliably. However, even based on very intense terrestrial sampling, uncertainties remain high $[133,139,140]$. Consequently, we need terrestrial inventory data complemented by remotely sensed data for informing carbon stock changes. For example, Næsset et al. [137••] showed a relative efficiency of such approaches of up to 3.6 when using remotely sensed data as auxiliary information. This would mean that we could achieve the same precision as with conventional field sampling with a sampling density reduced by the factor of 3.6. Where a conventional inventory would need 360 plots to achieve the desired precision, the approach using remotely sensed data as auxiliary information would only need 100 samples to obtain the same precision.

Importantly, inventory data for carbon stock estimates needs very high precision so that a reliable assessment of carbon stock changes is possible. While Grussu et al. [141] recommended achieving a standard error of $5 \%$ when sampling the carbon stock, this precision is likely not sufficient for measuring carbon stock changes with appropriate precision. An undifferentiated recommendation of one desirable level of precision is problematic, because there is no scientific support for such guidance [142]. For example, a standard error for a carbon stock estimate of 5\% may mean a standard error for the carbon stock change of close to $50 \%$, even if permanent sample plots are available to achieve the so far highest possible precisions for forest stock changes. We will show this assuming a carbon stock change in a forest from 113 to $123 \mathrm{Mg}$ per hectare. Referring to Grussu et al. [141], we let both stock estimates be associated with a standard error of 5\% and measured on permanent sample plots, showing a correlation of $\rho=0.7$ for the carbon stock measurements of two successive inventories. We can then combine the absolute standard errors of both stocks, \pm 5.65 and \pm 6.15 , to obtain the standard error $\left(s_{\overline{\Delta C}}\right)$ of the stock change of $+10 \mathrm{Mg}$ per hectare as (Eq. (1)):

$s_{\overline{\Delta C}}=\sqrt{5.65^{2}+6.15^{2}-2 \cdot 0.7 \cdot 5.65 \cdot 6.15}= \pm 4.59$

Given a stock change of $+10 \mathrm{Mg}$ per hectare, the standard error of the change amounts to $\sim 46 \%$. This means that a commonly recommended "desirable" standard error of $5 \%$ will likely not translate to similar precisions for estimates of stock changes. We will further address this important topic in one of the case studies concluding our paper.

\section{Where Do Forests Supply ES and Where Is Their Demand?}

Providing spatially explicit information comprises the creation of maps. Such ES maps may show the supply or the demand for ES. In recent years, the mapping of ES has advanced substantially [143-145]. Mapping the supply of ES dominates so far, while studies mapping the demand are less frequent. Maps can show information for polygons obtained by delineating the reference units (e.g. land-cover classes, forest stand types) or by providing gridded information [146].

Tiered approaches have been proposed for mapping ES [147]. ES mapping may address the range from local [148] to global scales [149]. Under such approaches, information on the provisioning of ES may build on "service providing units" (SPU), which comprise the full collection of organisms needed to deliver a specific ES [150]. For practical reasons, however, land-cover classes will frequently provide the reference units, where a land-cover class is a spatially explicit biophysical landscape unit [151]. Tier 1 maps provide the simplest approach using land-cover maps associated with expert judgement of the ES that certain land-cover classes can provide. Tier 2 maps add statistical data for provisioning ES as attributes to the various land-cover classes. Tier 3 maps involve process-based and empirical models to estimate the level of ES [143].

Changes in the capacity of a landscape to provide ES may depend on changes in the allocation of land to the reference units. Information on land cover is available from various sources, for example through (1) classification of satellite images; (2) available CORINE Land Cover data [152] and (3) global land-cover information provided by the Copernicus Climate Change Service. The latter is part of the Climate Change Initiative (CCI) of the European Space Agency (ESA) [153]. Other information can come from models like LUISA, maintained by the Joint Research Center (JRC) [154] or from the land-cover data provided by the European field survey program LUCAS [155].

Forest mapping is a major component of forest inventory [156]. For example, Vauhkonen and Ruotsalainen [46] have used wall-to-wall information based on pixels to model the contribution of forests to a range of management objectives, including biodiversity promotion, the attractiveness for recreation and carbon storage. In an advanced approach, Vauhkonen [30*0] has improved this type of modelling based on ALS data and achieved much higher precision in the prediction of ES levels than is achieved based on common resource maps. This approach offers very interesting future perspectives to improve supply maps for forest ES, which will facilitate informed decision-making and prioritisation of areas for the provisioning of specific ES. Such mapping of forest biodiversity, supported by remotely sensed data, is of particular importance. For example, Bae et al. [157] used satellite- 
borne RADAR data for mapping various facets of biodiversity for multiple taxa across several regions in central Europe. Asner et al. [158] provided an example for mapping forest trait diversity. For the case of forest carbon storage, mapping studies are also common [159].

Although less often applied in the context of ES, the mapping of the demand for forest functions started back in the 1950s. In Germany and other European countries, this type of mapping has become common in part due to the theory of so-called social forest functions, established by Viktor Dieterich [160]. Such forest function maps (sometimes also called forest development maps or regional forest plans) are legal instruments, for example in Germany, to account for the public demand for specific ES, such as protection and recreation. Forest function maps support regional forest planning and are demand oriented by nature. For example, the pragmatic mapping of forest functions commonly identifies forest with high priority for recreation where appropriate infrastructure is available (e.g. beer gardens or guesthouses). As another example, forest function planners pragmatically delineate forest with priority for protection on steep slopes, where forests protect railways or buildings against gravitational natural hazards. Tiemann and Ring [161] have suggested aligning existing forest function mapping and the mapping of forest ES.

One could debate whether the demand for ES is a concern of forest inventory. While numerous studies on mapping ES focus mainly on supply [162], we think that forest inventory should support the tradition of demand-based mapping of forest functions or ES. Forest inventory may contribute valuable information to estimate the demand for forest ES. Modern mapping of the demand for ES builds almost exclusively on socio-economic data [146], which is not the domain of forest inventory. However, forest inventory may well improve demand estimates by appropriate forest structural criteria. Economists measure demand for goods and services based on people's preferences, often expressed by their willingness to pay. For example, in an informative study on the opportunity for recreation, Termansen et al. [163••] used choice modelling and a GIS technique to derive visitor's willingness to pay for obtaining access to individual recreational forest sites in Denmark. In addition to infrastructural criteria, Termansen et al. used the proportion of broadleaves and the edge fraction of natural areas as important attributes to estimate the demand for recreation. As another example, Watson et al. [164] have shown how mapping the demand for recreation (and two other ES) may improve conservation planning. Zhao and Sander [165] have suggested mapping the demand for carbon storage based on local anthropogenic $\mathrm{CO}_{2}$ emissions. However, forest inventory likely has nothing to deliver for mapping the demand for carbon storage.

The prevailing practice in estimating the demand for ES is less informative for forest planning and so far mainly applied to regional, national or global scales, and therefore not limited to forestland. An increasing number of studies use already existing economic evaluations to describe the demand for ES [166-173]. These economic values derive from studies carried out elsewhere [10]. Using the results of an economic evaluation obtained from a primary study site (elsewhere) to inform about the assumed value of ES at a secondary (policy) site has been established as the benefit transfer method [174]. Applying the economic value for an ES obtained from the literature as an indicator for demand would only need very coarse information on the forest type (for example at biome level, whether tropical, temperate or boreal forest), but the link to more specific forest information has been lacking until now. Vice versa, the information provided by the existing databases on such economic valuation results for forest planning is limited. Müller et al. [10] have published a recent review on this topic showing an extreme variation of such economic valuation for certain ES, too large to be meaningfully applied to inform forest management planning.

Using economic ES values as the basis to estimate the demand builds on peoples' willingness to pay for ES. Willingness to pay is variable in space (e.g. demand for recreation), time (changing income levels and preferences will influence willingness to pay) and in other aspects of the socio-economic and ecological context (e.g. different preferences for specific forest structures). Only very few studies have managed to consider this variability appropriately, whereas forest inventory could help improve it. For example, changes in land cover, as commonly assumed in the studies monitoring changes in the economic value of ES [173], will influence the supply of ES, but not necessarily their demand. A substantial change in ES supply will alter the marginal economic value of ES, i.e. the willingness to pay for a small change in the level of an ES.

This might have the consequence that the actual economic value of an area-based reference unit (i.e. area times value coefficient) would hardly change when reducing the area, because scarcity-related increases in the per hectare value would compensate for the reduced area (Fig. 3). Combining willingness to pay estimates with area changes measured by forest inventory could help update the area-related economic values.

An economically more sophisticated approach could build on utility functions, which would help address an increasing scarcity of ES. For example, Nordhaus [175] implemented utility functions into his model to assess the social costs of carbon, but most studies on the value of ES still ignore the effects when such ES become scarcer. However, ignoring the variability of the willingness to pay for ES in mapping studies often makes their information unreliable and sometimes makes it less useful.

As an alternative to the prevailing use of coarse and sometimes unreliable information on economic ES value to map the demand for ES, measuring specific forest attributes by forest inventories could improve modelling the demand for ES and 


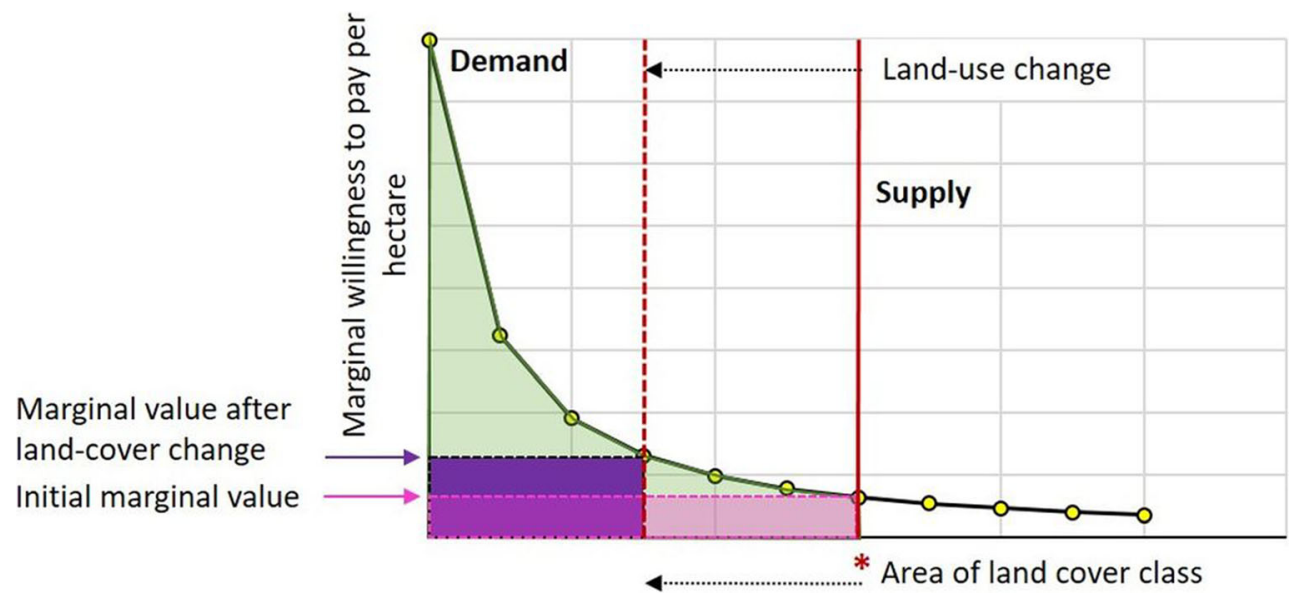

Fig. 3 Change in the marginal willingness to pay for ES, when the area of a certain land-cover class is reduced, for example when tropical forests shrink in their area due to deforestation (see Paul et al. [13], supplementary information, for a similar example). Note that we used a

biodiversity on a spatially explicit basis. This information could be combined with sophisticated choice modelling techniques, for example based on the method published by Termansen et al. [163••]. Consequently, in conjunction with stakeholder/visitor information, providing spatial information on forest attributes listed in Table 3 would support informative maps showing the demand for non-provisioning ES and biodiversity.

\section{Case Studies}

\section{Informing a Landscape Recreation Index by Forest Structural Criteria}

In a study on forest management for both timber production and the opportunity of recreation, Eggers et al. [32] have developed a landscape recreation index to quantify the appropriateness of a forest for recreation. The decision variable used for the optimization in this example study was "when to harvest trees/stands?" (i.e. optimal rotation). The aim of the study by Eggers et al. [32] was balancing the attractiveness for recreation, inter alia influenced by the rotation-length-dependent number of large trees and economic efficiency. In addition, their recreation index would allow for optimising other variables by asking "how much deadwood (standing and lying), which forest type and which reduction of soil damages would be optimal?" The index combines aspects of forest stand structure (forest stand index) and information on the location of the forest stand as well as the availability of open water bodies (location index). While maps on the locations of the forest stands (how close to the places of residence of potential visitors) and the presence of open water bodies in combination with GIS analyses will inform the location index, the forest stand index uses forest structural criteria as contained in somewhat unusual supply curve, suggested by Costanza et al. [166] for essential (non-substitutable) ES. However, the effect we show would also apply, if we had used a "normal" supply curve, with a slope greater than zero and smaller than infinity.

Table 3 of our review. The structural criteria include, for example information on deadwood, stand type, tree species proportions and the number of large trees (Fig. 4).

The number of large trees (positive influence compared with homogenous forest) and the amount of lying deadwood

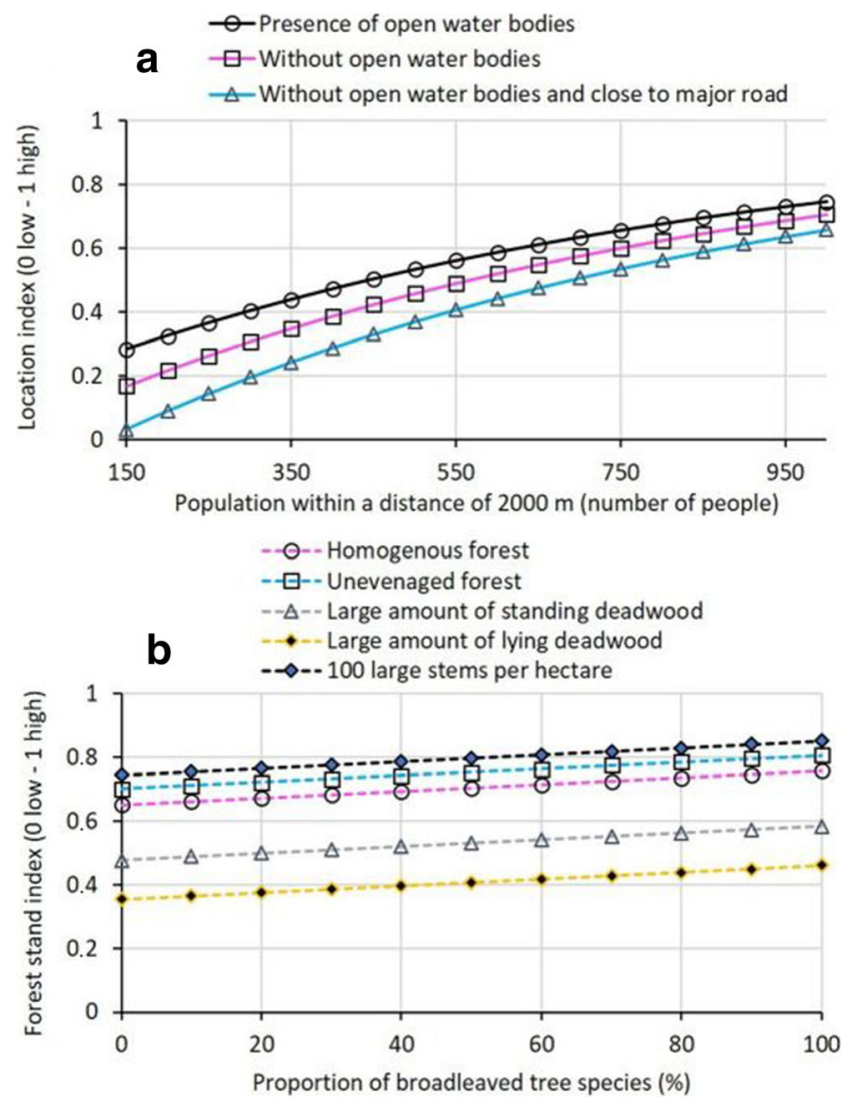

Fig. 4 Influence of location and decision criteria on the attractiveness of a landscape for recreation. Values close to one indicate high attractiveness for recreation. The recreation index is the product of a the location index and $\mathbf{b}$ the forest stand index 
(negative influence) cause the largest variation in the forest stand index, while the location index uses information not under the control of forest managers. Newly designed inventories to monitor the partly uncommon forest structural data, such as the number of large trees and the amount of deadwood, would facilitate an assessment of the status of a forest concerning the recreation. In addition, such a recreation index, informed in part by forest inventory data, would help to evaluate if this ES improves or worsens over time.

\section{Is Inventory Information Influential for Promoting Biodiversity Conservation?}

We have derived various previously uncommon attributes that future forest inventories could record to improve forest management planning. However, the attributes that would mostly have an impact on the planning decisions are unclear. As we did not find a forest science study providing an analysis of influential, but previously uncommon decision criteria, we came back to a land-use study that simulated deforestation scenarios. In this example study, the decision variables were the area proportions allocated to certain land-use/land-cover types. These simulations were based on various attributes of land-use/land-cover types, defined as decision criteria [176], some of which are obtained by terrestrial sampling and others by modelling or household surveys. Future forest research could carry out similar studies to elucidate the importance of considering the aforementioned forest attributes as criteria for decisions on a forest's composition and management.

The land-use study mentioned above tested how the consideration of multiple socio-economic and ecological criteria would influence the allocation of land in a still forested region in tropical South Ecuador (Fig. 5). This consideration does not mean that we expect forest inventory to deliver all socio-economic, multiple model-based and household survey information needed for simulating decision-making. Rather, we want to show the possible influence of inventory data (e.g. for species richness or carbon stocks), given that decision-making would also integrate many other criteria.

The analysis shows that considering the species richness of the land-use/land-cover types as a decision criterion had a major influence on deforestation scenarios (Fig. 5 a). Due to the importance of the species richness, the very species-rich natural forests obtained much higher weight in the future landscape composition so that deforestation was much reduced. Carbon storage was also important. Excluding this criterion has led to higher deforestation than considering the full set of criteria.

Based on similar analyses for predicting the future composition and management of forests [177], multi-criteria optimisation could support finding influential forest attributes. Future inventories could then prioritise collecting data for providing such particularly influential information.

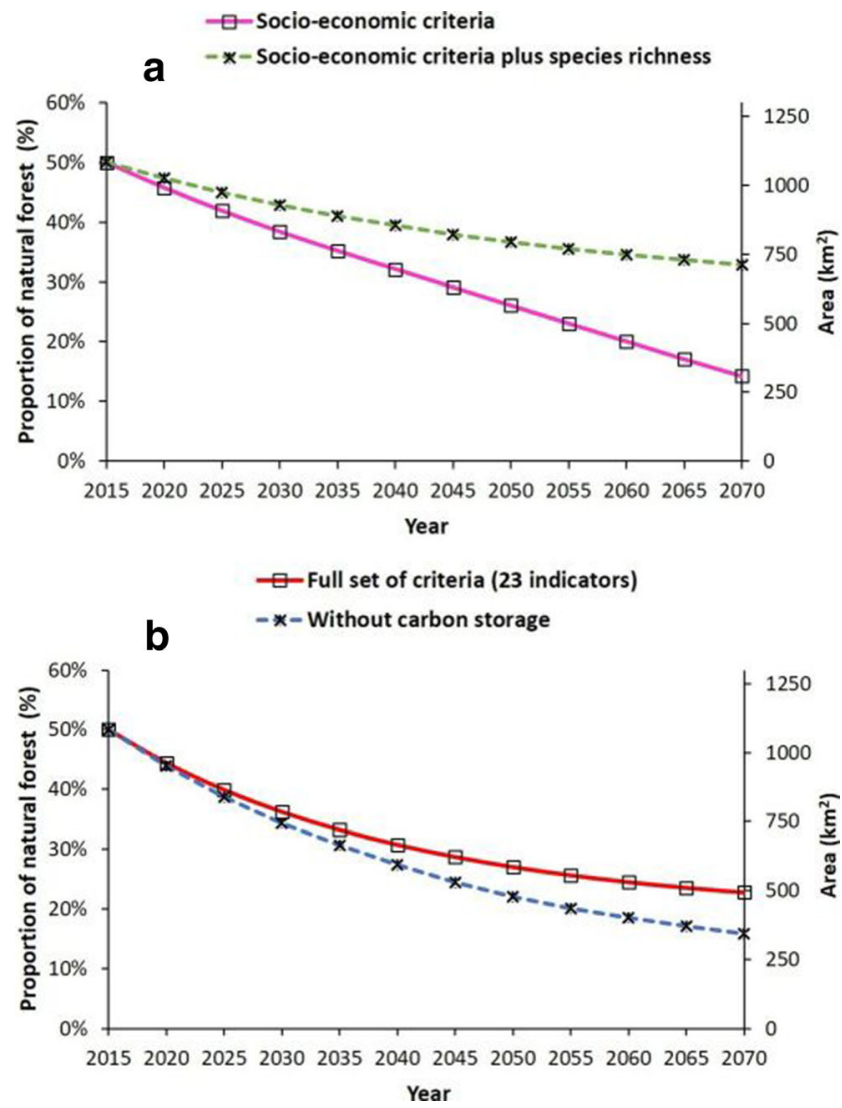

Fig. 5 Influence of various sets of decision criteria on simulated deforestation scenarios for a region in South Ecuador. Part a shows how considering species richness (number of vascular plant species) in addition to socio-economic criteria would influence the proportion of natural forest, while part $\mathbf{b}$ demonstrates the importance of indicators for carbon storage for the proportion of natural forest, when carbon storage is one aspect among many others

\section{Inventory Challenges to Quantify Carbon Stock Changes}

Forest inventory can provide value by reducing information uncertainty $[178-180,181 \bullet \cdot]$. With the term uncertainty, we refer to our limited knowledge on the true level of a specific criterion we have measured. One would usually quantify the uncertainty of such inventory information by the standard error of the sampled variable. We will illustrate the possible impact of the uncertainty of inventory information on decision-making with an example addressing the inclusion of private forest owners into initiatives to enhance the carbon storage in existing forests [182]. We assume that forest owners may generate carbon credits, which are tradable at voluntary carbon markets, if forest owners can show increased carbon storage in their forests. Certain providers of $\mathrm{CO}_{2}$ compensation opportunities would buy such carbon credits, for example to offer compensation opportunities to passengers for the emissions caused by their flying activities. The quantification of such carbon stock changes should follow the principle of conservativeness [183] to enhance credibility. Consequently, Köhl et al. [139] recommend using the lower $95 \%$ confidence limit to quantify carbon 
stock changes. Forest inventory must then make sure of an appropriate precision of data on forest carbon stocks. In the following, we will use a simplified example to demonstrate the importance of the precision of carbon stock estimates for such initiatives to enhance carbon stocks in existing forests. The decision variable in this example consideration was the desirable standard error in support of measuring carbon stock changes.

For our illustrative example, we assume an intended change of the carbon stock represented by the standing timber volume of $10 \mathrm{Mg}$ per hectare (over 30 years), which equals about 29 cubic metres of timber volume. Following the principle of conservativeness, we assume that possible buyers accept only the lower confidence limit of the reported carbon stock change to estimate the generated carbon credit, $C_{\text {credit }}$ (Eq. (2)).

$C_{\text {credit }}=\Delta C_{\text {Stock }}-t \cdot r S_{\overline{\Delta c}} \cdot \Delta C_{\text {Stock }}=\Delta C_{\text {Stock }} \cdot\left(1-t \cdot r S_{\overline{\Delta c}}\right)(2$

Equation (2), with $\Delta C_{\text {Stock }}$ as the expected carbon stock change, shows that the carbon credits decrease proportionally with an increasing tolerated relative standard error of the carbon stock change, $r S_{\overline{\Delta c}}$. Figure 6 mirrors this effect based on the expected revenues from selling the carbon credits. For example, if we assume a value of $t=1.96$ for constructing confidence limits, which include the true mean with $95 \%$ probability, we see that we can hardly generate any carbon credit, given a relative standard error of $50 \%$ of the carbon stock change. The value of $50 \%$ appears high, but we should bear in mind that quantifying carbon stock changes associated with this uncertainty already requires a quantification of carbon stocks with a relative standard error of not much more than $5 \%$.
We derived the costs building on the number of samples needed as follows (Eq. (3)).

$n=\frac{V_{\Delta c}^{2}}{r S_{\overline{\Delta c}}^{2}}$

$V_{\Delta c}$ is the variation coefficient of the carbon stock change. As the stock changes are usually small, but burdened with the standard error of estimating the whole carbon stock at both successive inventories, the variation coefficient $V_{\Delta c}$ is very high for stock changes. In our example, we assumed a variation coefficient $V_{c}$ of 0.53 for the carbon stock, which results in a variation coefficient $V_{\Delta c}$ for carbon stock changes of 4.87 (even when assuming a correlation between plot-based carbon stocks of two inventories of $\rho=0.7$ ).

The results for the optimal precision to estimate the carbon stock change now depend heavily on the size of the forest under consideration. For example, given a forest with a 500-ha area and using the lower bound of a 95\% confidence interval to estimate the carbon credit, the "optimal" precision was $r S_{\overline{\Delta c}}$ $=0.23$ for stock changes and $r S_{\bar{c}}=0.024$ for each of the successively sampled carbon stocks. The discounted profit was 160 Euro per hectare and the optimum sampling density was 0.91 plots per hectare. In contrast, for a forest with 15,000 ha, the "optimal" precision was $r S_{\overline{\Delta c}}=0.08$ for stock changes and $r S_{\bar{c}}=0.009$ for sampling the successive carbon stocks. For this larger forest, the profit per hectare was 394 Euro and the desirable sampling density was 0.25 plots per hectare.

Less conservative assumptions (e.g. a $68 \%$ confidence limit associated with $t=1$ ) would allow higher profits (Fig. 5). Considering larger changes per hectare could improve the economic consideration. Higher profits may also result from
Fig. 6 Influence of the precision of estimates for carbon stock changes on possible revenues and costs from enhancing the carbon stock represented by the standing timber volume by $10 \mathrm{Mg}$ per hectare (over a period of 30 years). We assumed a price of 91.75 (25 Euro per $\mathrm{Mg}$ of $\mathrm{CO}_{2}$ ) for storing 1 additional $\mathrm{Mg}$ carbon per hectare. We discounted revenues with a factor of $2 \%$ over 30 years. For the costs of one sample plot, we assumed 130 Euro

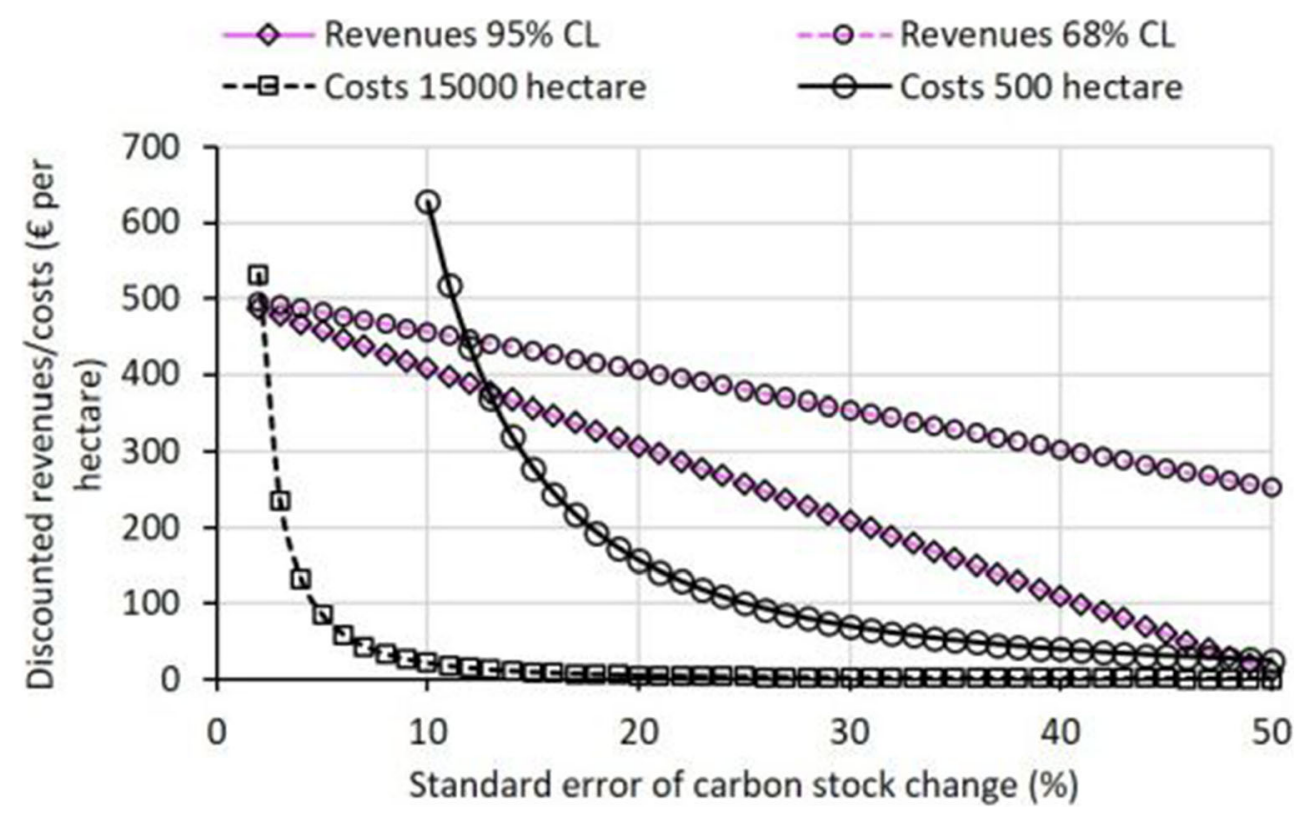

Standard error of carbon stock change (\%) 
considerations at the national level, for example when reducing deforestation and forest degradation [139]. Moreover, when using remote sensing techniques to stratify forest area or to provide auxiliary information, the precision of terrestrial sampling may improve $[137,184]$.

\section{Conclusions}

Most papers addressing the inventory of ES are technical by nature. Technical advances may indeed substantially improve the quality of inventory information. However, we think that identifying new forest attributes, well aligned with the preferences of stakeholders, would bring research and practice of the inventory of ES substantially forward. A benefit provided by information lies in reducing uncertainty, which results in better decision-making [185]. Reducing information uncertainty embraces at least two aspects: clarity about the type of information decision-makers would need and about the required degree of precision. We have focused on the first aspect by discussing new, and currently rather uncommon inventory criteria to describe the preferences of stakeholders and to integrate the opportunity of recreation, biodiversity promotion and carbon storage into forest planning. A roadmap to develop the inventory further, in supporting forest-related planning for the provision of ecosystem services and biodiversity, may include:

1) Establishing further innovative decision criteria associated with stakeholder preferences, which future inventories may inform by measuring appropriate forest attributes.

2) To achieve (1), future inventories may benefit from the evaluation of a number of existing and sophisticated choice experiments as well as choice modelling studies.

3) The standard plot-based field inventories will not deliver some informative criteria in the most effective manner. Future inventory concepts would thus need to integrate various inventory techniques and multiple data sources. Forest inventory science needs to find holistic forest inventory management systems to couple various inventory concepts in support of the integration of ES into forest planning (see Woudenberg et al. [186] for possible database organisation and management).

4) Recreation indices require forest structural information and visitor information. Future inventory systems may partly inform the demand side for recreation services by providing distance information to the residence places of potential visitors, the presence of open water bodies and forest information on visitors' preferred forest structural attributes.

5) We need more efficient inventory concepts for "rare events", for example addressing the criteria deadwood, rare species, habitat trees and tall trees. They provide important information not only for the opportunity of recreation but in particular for the promotion of biodiversity. Future inventory concepts need better integration of functions to estimate inclusion probabilities, informing terrestrial point-transect and line intersect inventory techniques and possibly remote sensing techniques to quantify the aforementioned rare events.

6) Methodology for precise estimation of carbon stock changes needs further attention. The potential of using remotely sensed data as auxiliary information to enhance the precision of carbon stock change may provide a rewarding future field of research [137••].

7) Future inventory concepts may also inform mapping the demand for ES, which studies have hardly considered as a field of research in forest inventory so far. The existing approaches based on economic ES values may benefit from building on the valuation of important forest attributes (delivered by inventory) obtained from choice experiments. Inventory systems focusing on specific forest attributes related to ES and biodiversity could thus provide basic information to create useful maps on the demand for ES and biodiversity.

8) Transforming forest attributes delivered from existing inventories into levels of expected ES may benefit from remote sensing technology and is a promising future line of research [30••]. This would enhance prioritisation of ES in supplyoriented maps and provide wall-to-wall information for large areas (e.g. biomass for further carbon considerations). Remote sensing-based technology may also enhance the efficiency of terrestrial sampling by facilitating effective stratification and providing informative auxiliary data.

Acknowledgements The authors of this review have received funds from the project NOBEL, "Novel business models and mechanisms for the sustainable supply of and payment for forest ecosystem services", which is part of the ERA-NET Cofund ForestValue. ForestValue is a project of the European Union's Horizon 2020 program, grant agreement $\mathrm{N}^{\circ}$ 773324. Thomas Knoke is also grateful for the funding of the project "Bringing Uncertain Ecosystem Services into Forest Optimization" by the German Science Foundation (KN 586/171). We thank Alena Chilian and Juanita Schmidhammer for the language editing of the manuscript.

Funding Open Access funding enabled and organized by Projekt DEAL.

Open Access This article is licensed under a Creative Commons Attribution 4.0 International License, which permits use, sharing, adaptation, distribution and reproduction in any medium or format, as long as you give appropriate credit to the original author(s) and the source, provide a link to the Creative Commons licence, and indicate if changes were made. The images or other third party material in this article are included in the article's Creative Commons licence, unless indicated otherwise in a credit line to the material. If material is not included in the article's Creative Commons licence and your intended use is not permitted by statutory regulation or exceeds the permitted use, you will need to obtain permission directly from the copyright holder. To view a copy of this licence, visit http://creativecommons.org/licenses/by/4.0/. 


\section{References}

Papers of particular interest, published recently, have been highlighted as:

- Of importance

- Of major importance

1. Bettinger P, Boston K, Siry JP, Grebner DL. Forest management and planning. 2nd ed. London, United Kingdom: Academic Press; 2017.

2. Knoke T. Forest Management. In: Köhl M, Pancel L, editors. Tropical forestry handbook. Heidelberg: Springer Nature; 2015. https://doi.org/10.1007/978-3-642-41554-8_139-1.

3. Díaz S, Pascual U, Stenseke M, Martín-López B, Watson RT, Molnár Z, et al. Assessing nature's contributions to people. Science. 2018;359:270-2. https://doi.org/10.1126/science. aap8826.

4. Lamothe KA, Dong H, Senar OE, Teichert S, Creed IF, Kreutzweiser DP, et al. Demand for nonprovisioning ecosystem services as a driver of change in the Canadian boreal zone 1. Environ. Rev. 2019;27:106-23. https://doi.org/10.1139/er-20180065.

5. Adams H, Neil AW. The contribution of ecosystem services to place utility as a determinant of migration decision-making. Environ. Res. Lett. 2013;8:15006. https://doi.org/10.1088/17489326/8/1/015006.

6. Pukkala T. Multi-objective forest planning. Dordrecht, London: Springer; 2011.

7. Miles PD. Using biological criteria and indicators to address forest inventory data at the state level. Forest Ecology and Management. 2002;155:171-85. https://doi.org/10.1016/S0378-1127(01) 00557-6.

8. Köhl M, Marchetti M. Objectives and Planning of Forest Inventories. In: Köhl MPL, editor. Tropical forestry handbook. Heidelberg: Springer; 2015. p. 749-76. https://doi.org/10.1007/ 978-3-642-54601-3 70.

9. Frické MH. Data-information-knowledge-wisdom (DIKW) pyramid, framework, continuum. In: Schintler LA, Mc Neely CL, editors. Encyclopedia of big data. Cham: Springer International Publishing; Imprint: Springer; 2019. https://doi.org/10.1007/9783-319-32001-4_331-1.

10. Müller A, Knoke T, Olschewski R. Can Existing Estimates for Ecosystem Service Values Inform Forest Management? Forests. 2019;10:132. https://doi.org/10.3390/f10020132.

11. Haines-Young RH, Potschin M. Common International Classification of Ecosystem Services (CICES) V5.1: guidance on the application of the revised structure. https://cices.eu/ content/uploads/sites/8/2018/01/Guidance-V51-01012018.pdf.

12. United Nations. Convention on Biological Diversity. 1992. https://reaties.un.org/doc/Treaties/1992/06/19920605\%200844\%20PM/Ch_XXVII_08p.pdf.

13. Paul C, Hanley N, Meyer ST, Fürst C, Weisser WW, Knoke T. On the functional relationship between biodiversity and economic value. Science Advances. 2020;6:eaax7712. https://doi.org/10. 1126/sciadv.aax7712.

14. Martínez-Jauregui M, White PCL, Touza J, Soliño M. Untangling perceptions around indicators for biodiversity conservation and ecosystem services. Ecosystem Services. 2019;38:100952. https://doi.org/10.1016/j.ecoser.2019.100952.

15. Fraser JA, Diabaté M, Narmah W, Beavogui P, Guilavogui K, de Foresta $\mathrm{H}$, et al. Cultural valuation and biodiversity conservation in the Upper Guinea forest. West Africa. E\&S. 2016;21. https:// doi.org/10.5751/ES-08738-210336.
16. Rammig A. Tropical carbon sinks are saturating at different times on different continents. Nature. 2020;579:38-9. https://doi.org/10. 1038/d41586-020-00423-8.

17. Krause A, Knoke T, Rammig A. A regional assessment of landbased carbon mitigation potentials: bioenergy, BECCS, reforestation, and forest management. GCB Bioenergy. 2020;12:346-60. https://doi.org/10.1111/gcbb.12675.

18. Sardeshpande M, Shackleton C. Wild edible fruits: a systematic review of an under-researched multifunctional NTFP (non-timber forest product). Forests. 2019;10:467. https://doi.org/10.3390/ f10060467.

19. Karun NC, Vaast P, Kushalappa CG. Bioinventory and documentation of traditional ecological knowledge of wild edible fruits of Kodagu-Western Ghats. India. J. For. Res. 2014;25:717-21. https://doi.org/10.1007/s11676-014-0513-7.

20. Schulp CJE, Thuiller W, Verburg PH. Wild food in Europe: a synthesis of knowledge and data of terrestrial wild food as an ecosystem service. Ecological Economics. 2014;105:292-305. https://doi.org/10.1016/j.ecolecon.2014.06.018.

21. Miina J, Pukkala T, Kurttila M. Optimal multi-product management of stands producing timber and wild berries. Eur J Forest Res. 2016;135:781-94. https://doi.org/10.1007/s10342-0160972-9.

22. Pukkala T, Lähde E, Laiho O, Salo K, Hotanen J-P. A multifunctional comparison of even-aged and uneven-aged forest management in a boreal region. Can. J. For. Res. 2011;41:851-62. https:// doi.org/10.1139/X11-009.

23. Kilpeläinen H, Salminen O, Härkönen K, Miina J, Kurttila M. Integrating bilberry yields into regional long-term forest scenario analyses. Scandinavian Journal of Forest Research. 2017;33:378 86. https://doi.org/10.1080/02827581.2017.1407821.

24. Andrew ME, Wulder MA, Nelson TA. Potential contributions of remote sensing to ecosystem service assessments. Progress in Physical Geography: Earth and Environment. 2014;38:328-53. https://doi.org/10.1177/0309133314528942 Very good general overview on remotely sensed data acquisition to support ecosystem services.

25. Galbraith SM, Vierling LA, Bosque-Pérez NA. Remote sensing and ecosystem services: current status and future opportunities for the study of bees and pollination-related services. Curr Forestry Rep. 2015;1:261-74. https://doi.org/10.1007/s40725-015-0024-6 Good overview on remotely sensed data acquisition to support pollination services.

26. Vargas L, Willemen L, Hein L. Assessing the capacity of ecosystems to supply ecosystem services using remote sensing and an ecosystem accounting approach. Environ Manage. 2019;63:1-15. https://doi.org/10.1007/s00267-018-1110-x.

27. Potschin M, Haines-Young RH, Fish R, Turner RK. editors. Routledge handbook of ecosystem services. London, New York: Routledge, Taylor \& Francis Group; 2016.

28. Boerema A, Rebelo AJ, Bodi MB, Esler KJ, Meire P, Rohr J. Are ecosystem services adequately quantified? J Appl Ecol. 2017;54: 358-70. https://doi.org/10.1111/1365-2664.12696.

29. Heinonen T, Pukkala T, Asikainen A. Variation in forest landowners' management preferences reduces timber supply from Finnish forests. Annals of Forest Science. 2020;77:1562. https:// doi.org/10.1007/s13595-020-00939-z.

$30 . \bullet$ Vauhkonen J. Predicting the provisioning potential of forest ecosystem services using airborne laser scanning data and forest resource maps. For Ecosyst. 2018;5:328. https://doi.org/10.1186/ s40663-018-0143-1 Excellent case study showing the potential of ALS data to enhance ES supply mapping.

31. Edwards D, Jay M, Jensen FS, Lucas B, Marzano M, Montagné C, et al. Public preferences for structural attributes of forests: towards a pan-European perspective. Forest Policy and Economics. 2012;19:12-9. https://doi.org/10.1016/j.forpol.2011.07.006. 
32. Eggers J, Lindhagen A, Lind T, Lämås T, Öhman K. Balancing landscape-level forest management between recreation and wood production. Urban Forestry \& Urban Greening. 2018;33:1-11. https://doi.org/10.1016/j.ufug.2018.04.016.

33. Giergiczny M, Czajkowski M, Żylicz T, Angelstam P. Choice experiment assessment of public preferences for forest structural attributes. Ecological Economics. 2015;119:8-23. https://doi.org/ 10.1016/j.ecolecon.2015.07.032.

34. Filyushkina A, Agimass F, Lundhede T, Strange N, Jacobsen JB. Preferences for variation in forest characteristics: does diversity between stands matter? Ecological Economics. 2017;140:22-9. https://doi.org/10.1016/j.ecolecon.2017.04.010.

35. Schirpke U, Meisch C, Marsoner T, Tappeiner U. Revealing spatial and temporal patterns of outdoor recreation in the European Alps and their surroundings. Ecosystem Services. 2018;31:33650. https://doi.org/10.1016/j.ecoser.2017.11.017.

36. Blattert C, Lemm R, Thees O, Hansen J, Lexer MJ, Hanewinkel $M$. Segregated versus integrated biodiversity conservation: valuebased ecosystem service assessment under varying forest management strategies in a Swiss case study. Ecological Indicators. 2018;95:751-64. https://doi.org/10.1016/j.ecolind.2018.08.016.

37. Meyerhoff J, Liebe U, Hartje V. Benefits of biodiversity enhancement of nature-oriented silviculture: evidence from two choice experiments in Germany. JFE. 2009;15:37-58. https://doi.org/ 10.1016/j.jfe.2008.03.003.

38. Czajkowski M, Buszko-Briggs M, Hanley N. Valuing changes in forest biodiversity. Ecological Economics. 2009;68:2910-7. https://doi.org/10.1016/j.ecolecon.2009.06.016.

39. Cerda C, Ponce A, Zappi M. Using choice experiments to understand public demand for the conservation of nature: a case study in a protected area of Chile. Journal for Nature Conservation. 2013;21:143-53. https://doi.org/10.1016/j.jnc.2012.11.010.

40. Morris EK, Caruso T, Buscot F, Fischer M, Hancock C, Maier TS, et al. Choosing and using diversity indices: insights for ecological applications from the German Biodiversity Exploratories. Ecol Evol. 2014;4:3514-24. https://doi.org/10.1002/ece3.1155.

41. Eggleston HS, Buendia L, Miwa K, Tanabe TN. 2006 IPCC guidelines for national greenhouse gas inventories. Hayama, Japan: Institute for Global Environmental Strategies; 2006.

42. Nordström E-M, Nieuwenhuis M, Başkent EZ, Biber P, Black K, Borges JG, et al. Forest decision support systems for the analysis of ecosystem services provisioning at the landscape scale under global climate and market change scenarios. Eur J Forest Res. 2019;138:561-81. https://doi.org/10.1007/s10342-019-01189-Z.

43. Blattert C, Lemm R, Thees O, Lexer MJ, Hanewinkel M. Management of ecosystem services in mountain forests: review of indicators and value functions for model based multi-criteria decision analysis. Ecological Indicators. 2017;79:391-409. https://doi.org/10.1016/j.ecolind.2017.04.025.

44. Delgado-Aguilar MJ, Hinojosa L, Schmitt CB. Combining remote sensing techniques and participatory mapping to understand the relations between forest degradation and ecosystems services in a tropical rainforest. Applied Geography. 2019;104:65-74. https:// doi.org/10.1016/j.apgeog.2019.02.003.

45. van der Plas F, Ratcliffe S, Ruiz-Benito P, Scherer-Lorenzen M, Verheyen K, Wirth C, et al. Continental mapping of forest ecosystem functions reveals a high but unrealised potential for forest multifunctionality. Ecol Lett. 2018;21:31-42. https://doi.org/10. 1111/ele.12868.

46. Vauhkonen J, Ruotsalainen R. Assessing the provisioning potential of ecosystem services in a Scandinavian boreal forest: suitability and tradeoff analyses on grid-based wall-to-wall forest inventory data. Forest Ecology and Management. 2017;389:272-84. https://doi.org/10.1016/j.foreco.2016.12.005.

47. Huang J-H, Lu X-H, Guo Z-J, Wang J-P, Zang R-G. Assessment of natural forest ecosystem services in Buerjin County, Xinjiang.
Beijing Linye Daxue Xuebao/Journal of Beijing Forestry University. 2015;37:62-9.

48. Nagendra H. Opposite trends in response for the Shannon and Simpson indices of landscape diversity. Applied Geography. 2002;22:175-86. https://doi.org/10.1016/S0143-6228(02)000024.

49. Picos J, Bastos G, Míguez D, Alonso L, Armesto J. Individual tree detection in a eucalyptus plantation using unmanned aerial vehicle (UAV)-LiDAR. Remote Sensing. 2020;12:885. https://doi.org/10. 3390/rs12050885.

50. Kleinn C, Kändler G, Schnell S. Estimating forest edge length from forest inventory sample data. This article is one of a selection of papers from Extending Forest Inventory and Monitoring over Space and Time. Can. J. For. Res. 2011;41:1-10. https://doi.org/ 10.1139/X10-182.

51. Heurich M, Ochs T, Andresen T, Schneider T. Object-orientated image analysis for the semi-automatic detection of dead trees following a spruce bark beetle (Ips typographus) outbreak. Eur J Forest Res. 2010;129:313-24. https://doi.org/10.1007/s10342009-0331-1.

52. Koivuniemi J, Korhonen KT. Inventory by compartments. In: Kangas A, Maltamo M, editors. Forest Inventory. Dordrecht: Kluwer Academic Publishers; 2006. p. 271-8. https://doi.org/10. 1007/1-4020-4381-3 16.

53. Liu L, Pang Y, Li Z, Si L, Liao S. Combining airborne and terrestrial laser scanning technologies to measure forest understorey volume. Forests. 2017;8:111. https://doi.org/10.3390/f8040111.

54. Hardy A, Ettritch G, Cross D, Bunting P, Liywalii F, Sakala J, et al. Automatic detection of open and vegetated water bodies using Sentinel 1 to map African malaria vector mosquito breeding habitats. Remote Sensing. 2019;11:593. https://doi.org/10.3390/ rs11050593.

55. Mandlburger G, Pfennigbauer M, Pfeifer N. Analyzing near water surface penetration in laser bathymetry \&ndash; a case study at the River Pielach. ISPRS Ann. Photogramm. Remote Sens. Spatial Inf. Sci. 2013;II-5/W2:175-80. https://doi.org/10.5194/ isprsannals-II-5-W2-175-2013.

56. Fischer C, Traub B. Swiss National Forest Inventory - methods and models of the fourth assessment. Cham, Switzerland: Springer Nature; 2019.

57. Eguiguren P, Fischer R, Günter S. Degradation of ecosystem services and deforestation in landscapes with and without incentivebased forest conservation in the Ecuadorian Amazon. Forests. 2019;10:442. https://doi.org/10.3390/f10050442.

58. van Houtven G, Phelan J, Clark C, Sabo RD, Buckley J, Thomas $\mathrm{RQ}$, et al. Nitrogen deposition and climate change effects on tree species composition and ecosystem services for a forest cohort. Ecol Monogr. 2019;89:e01345. https://doi.org/10.1002/ecm. 1345.

59. Las-Casas FMG, Pereira IMS, dos Santos LN, Naka LN. The avifauna of the Catimbau National Park, an important protected area in the Brazilian Semiarid. Revista Brasileira de Ornitologia. 2019;27:79-93.

60. Storch F, Dormann CF, Bauhus J. Quantifying forest structural diversity based on large-scale inventory data: a new approach to support biodiversity monitoring. For. Ecosyst. 2018;5:230. https:// doi.org/10.1186/s40663-018-0151-1.

61. Pan Y, McCullough K, Hollinger DY. Forest biodiversity, relationships to structural and functional attributes, and stability in New England forests. For. Ecosyst. 2018;5:179. https://doi.org/ 10.1186/s40663-018-0132-4.

62. Staudhammer CL, Escobedo FJ, Blood A. Assessing methods for comparing species diversity from disparate data sources: the case of urban and peri-urban forests. Ecosphere. 2018;9:e02450. https://doi.org/10.1002/ecs2.2450. 
63. Speak A, Escobedo FJ, Russo A, Zerbe S, Garcia C. Comparing convenience and probability sampling for urban ecology applications. J Appl Ecol. 2018;55:2332-42. https://doi.org/10.1111/ 1365-2664.13167.

64. Lecina-Diaz J, Alvarez A, Regos A, Drapeau P, Paquette A, Messier C, et al. The positive carbon stocks-biodiversity relationship in forests: co-occurrence and drivers across five subclimates. Ecol Appl. 2018;28:1481-93. https://doi.org/10.1002/eap.1749.

65. Granath G, Kouki J, Johnson S, Heikkala O, Rodríguez A, Strengbom J, et al. Trade-offs in berry production and biodiversity under prescribed burning and retention regimes in boreal forests. $\mathrm{J}$ Appl Ecol. 2018;55:1658-67. https://doi.org/10.1111/1365-2664. 13098.

66. Zhang T, Niinemets Ü, Sheffield J, Lichstein JW. Shifts in tree functional composition amplify the response of forest biomass to climate. Nature. 2018;556:99-102. https://doi.org/10.1038/ nature26152.

67. Fedele G, Locatelli B, Djoudi H, Colloff MJ. Reducing risks by transforming landscapes: cross-scale effects of land-use changes on ecosystem services. PLoS ONE. 2018;13:e0195895. https:// doi.org/10.1371/journal.pone.0195895.

68. Giannini TC, Giulietti AM, Harley RM, Viana PL, Jaffe R, Alves $\mathrm{R}$, et al. Selecting plant species for practical restoration of degraded lands using a multiple-trait approach. Austral Ecology. 2017;42:510-21. https://doi.org/10.1111/aec.12470.

69. CALVO-RODRIGUEZ S, SANCHEZ-AZOFEIFA AG, DURAN SM, ESPÍRITO-SANTO MM. Assessing ecosystem services in Neotropical dry forests: a systematic review. Envir. Conserv. 2017;44:34-43. https://doi.org/10.1017/ S0376892916000400.

70. RANA EAK, THWAITES RIK, LUCK G. Trade-offs and synergies between carbon, forest diversity and forest products in Nepal community forests. Envir. Conserv. 2017;44:5-13. https://doi.org/ 10.1017/S0376892916000448.

71. Alrahahleh L, Ikonen V-P, Kilpeläinen A, Torssonen P, Strandman H, Asikainen A, et al. Effects of forest conservation and management on volume growth, harvested amount of timber, carbon stock, and amount of deadwood in Finnish boreal forests under changing climate. Can. J. For. Res. 2017;47:215-25. https://doi.org/10.1139/cjfr-2016-0153.

72. Lu Z, Peters C, Ashton M, Feng J, Xue D. The effect of forest tenure on forest composition in a Miao Area of Guizhou. China. Mountain Research and Development. 2016;36:193-202. https:// doi.org/10.1659/MRD-JOURNAL-D-15-00057.1.

73. Schmid U, Bircher N, Bugmann H. Naturnaher und multifunktionaler Waldbau in Zeiten des Klimawandels - eine Fallstudie. Schweizerische Zeitschrift fur Forstwesen. 2015;166: 314-24. https://doi.org/10.3188/szf.2015.0314.

74. Meyer C, Kreft H, Guralnick R, Jetz W. Global priorities for an effective information basis of biodiversity distributions. Nat Commun. 2015;6:8221. https://doi.org/10.1038/ncomms9221.

75. Sutherland IJ, Gergel SE, Bennett EM. Seeing the forest for its multiple ecosystem services: indicators for cultural services in heterogeneous forests. Ecological Indicators. 2016;71:123-33. https://doi.org/10.1016/j.ecolind.2016.06.037 Very thorough and detailed example study with case-specific ES and indicators.

76. Elias GA, Gasper ALD, Lima JMT, Lodetti G, Santos RD. Native understory palms (Arecaceae) of the Atlantic Forest in Santa Catarina, Southern Brazil. Rodriguésia. 2018;69:693-8. https:// doi.org/10.1590/2175-7860201869230.

77. Bugalho MN, Dias FS, Briñas B, Cerdeira JO. Using the high conservation value forest concept and Pareto optimization to identify areas maximizing biodiversity and ecosystem services in cork oak landscapes. Agroforest Syst. 2016;90:35-44. https://doi.org/ 10.1007/s10457-015-9814-x.
78. Mežaka A, Putna S, Erta I. Evaluation and long-term conservation perspectives of woodland key habitat bryophyte and lichen indicators in Latgale. ETR. 2015;2:197. https://doi.org/10.17770/ etr2015vol2.283.

79. Gutsch M, Lasch-Born P, Kollas C, Suckow F, Reyer CPO. Balancing trade-offs between ecosystem services in Germany's forests under climate change. Environ. Res. Lett. 2018;13: 45012. https://doi.org/10.1088/1748-9326/aab4e5.

80. Ritter T, Saborowski J. Point transect sampling of deadwood: a comparison with well-established sampling techniques for the estimation of volume and carbon storage in managed forests. Eur J Forest Res. 2012;131:1845-56. https://doi.org/10.1007/s10342012-0637-2.

81. Huber N, Kienast F, Ginzler C, Pasinelli G. Using remote-sensing data to assess habitat selection of a declining passerine at two spatial scales. Landscape Ecol. 2016;31:1919-37. https://doi.org/ 10.1007/s10980-016-0370-1.

82. Fassnacht FE, Latifi H, Stereńczak K, Modzelewska A, Lefsky M, Waser LT, et al. Review of studies on tree species classification from remotely sensed data. Remote Sensing of Environment. 2016;186:64-87. https://doi.org/10.1016/j.rse.2016.08.013.

83. Immitzer M, Neuwirth M, Böck S, Brenner H, Vuolo F, Atzberger C. Optimal input features for tree species classification in Central Europe based on multi-temporal Sentinel-2 data. Remote Sensing. 2019;11:2599. https://doi.org/10.3390/rs11222599.

84. Teuscher M, Brandl R, Forster B, Hothorn T, Rosner S, Muller J. Forest inventories are a valuable data source for habitat modelling of forest species: an alternative to remote-sensing data. Forestry. 2013;86:241-53. https://doi.org/10.1093/forestry/cps081.

85. Thom D, Keeton WS. Stand structure drives disparities in carbon storage in northern hardwood-conifer forests. Forest Ecology and Management. 2019;442:10-20. https://doi.org/10.1016/j.foreco. 2019.03.053.

86. Forsius M, Akujärvi A, Mattsson T, Holmberg M, Punttila P, Posch M, et al. Modelling impacts of forest bioenergy use on ecosystem sustainability: Lammi LTER region, southern Finland. Ecological Indicators. 2016;65:66-75. https://doi.org/ 10.1016/j.ecolind.2015.11.032.

87. Yrttimaa T, Saarinen N, Luoma V, Tanhuanpää T, Kankare V, Liang X, et al. Detecting and characterizing downed dead wood using terrestrial laser scanning. ISPRS Journal of Photogrammetry and Remote Sensing. 2019;151:76-90. https://doi.org/10.1016/j. isprsjprs.2019.03.007.

88. Marchi N, Pirotti F, Lingua E. Airborne and terrestrial laser scanning data for the assessment of standing and lying deadwood: current situation and new perspectives. Remote Sensing. 2018;10:1356. https://doi.org/10.3390/rs10091356.

89. Feeley KJ, Silman MR, Franklin J. Disappearing climates will limit the efficacy of Amazonian protected areas. Diversity Distrib. 2016;22:1081-4. https://doi.org/10.1111/ddi.12475.

90. ZHANG Jiping 张, QIAO Qing 乔, LIU Chunlan 刘, WANG Haihua 王, PEI Sha 裴. Ecological land use planning for Beijing City based on the minimum cumulative resistance model. 生态学 报. 2017;37. https://doi.org/10.5846/stxb201606121121.

91. Pettorelli N. Schulte to Bühne H, Tulloch A, Dubois G, Macinnis$\mathrm{Ng} \mathrm{C}$, Queirós AM, et al. Satellite remote sensing of ecosystem functions: opportunities, challenges and way forward. Remote Sens Ecol Conserv. 2018;4:71-93. https://doi.org/10.1002/rse2. 59.

92. Bernier PY, Paré D, Stinson G, Bridge SRJ, Kishchuk BE, Lemprière TC, et al. Moving beyond the concept of "primary forest" as a metric of forest environment quality. Ecol Appl. 2017;27:349-54. https://doi.org/10.1002/eap.1477.

93. Pang Y, Li Z, Ju H, Lu H, Jia W, Si L, et al. LiCHy: The CAF's LiDAR. CCD and hyperspectral integrated airborne observation 
system. Remote Sensing. 2016;8:398. https://doi.org/10.3390/ rs8050398.

94. Zhang Z, Kazakova A, Moskal L, Styers D. Object-based tree species classification in urban ecosystems using LiDAR and hyperspectral data. Forests. 2016;7:122. https://doi.org/10.3390/ f7060122.

95. Elatawneh A, Rappl A, Rehush N, Schneider T, Knoke T. Forest tree species communities identification using multi phenological stages RapidEye data: case study in the forest of Freising. In: Borg E, Daedelow H, Johnson R, editors. RapidEye Science Archive (RESA) - From the Basics to the Service. Berlin: GITO Verlag; 2013. p. 21-38.

96. Wagner FH, Sanchez A, Tarabalka Y, Lotte RG, Ferreira MP, Aidar MPM, et al. Using the U-net convolutional network to map forest types and disturbance in the Atlantic rainforest with very high resolution images. Remote Sens Ecol Conserv. 2019;5: 360-75. https://doi.org/10.1002/rse2.111.

97. Winter S. Forest naturalness assessment as a component of biodiversity monitoring and conservation management. Forestry. 2012;85:293-304. https://doi.org/10.1093/forestry/cps004.

98. Orwin $\mathrm{KH}$, Wardle DA. New indices for quantifying the resistance and resilience of soil biota to exogenous disturbances. Soil Biology and Biochemistry. 2004;36:1907-12. https://doi.org/10. 1016/j.soilbio.2004.04.036.

99. Zörner J, Dymond J, Shepherd J, Wiser S, Jolly B. LiDAR-based regional inventory of tall trees-Wellington. New Zealand. Forests. 2018;9:702. https://doi.org/10.3390/f9110702.

100. Zhao C, Hou F, Song X, Wang N, Qi Y, Gou X, et al. Tightening ecological management facilitates green development in the Qilian Mountains. Chin. Sci. Bull. 2019;64:2928-37. https://doi.org/10. 1360/TB-2019-0209.

101. Zielewska-Büttner K, Heurich M, Müller J, Braunisch V. Remotely sensed single tree data enable the determination of habitat thresholds for the three-toed woodpecker (Picoides tridactylus). Remote Sensing. 2018;10:1972. https://doi.org/10. 3390/rs10121972.

102. Elatawneh A, Wallner A, Manakos I, Schneider T, Knoke T. Forest cover database updates using multi-seasonal RapidEye data-storm event assessment in the Bavarian Forest National Park. Forests. 2014;5:1284-303. https://doi.org/10.3390/ f5061284.

103. Hamdi ZM, Brandmeier M, Straub C. Forest damage assessment using deep learning on high resolution remote sensing data. Remote Sensing. 2019;11:1976. https://doi.org/10.3390/ rs11171976.

104. Adermann V, Padari A, Sirgmets R, Kosk A, Kaimre P. Valuation of timber production and carbon sequestration on Järvselja nature protection area. Forestry Studies. 2015;63:29-43. https://doi.org/ 10.1515/fsmu-2015-0007.

105. Stringer CE, Trettin CC, Zarnoch SJ, Tang W. Carbon stocks of mangroves within the Zambezi River Delta. Mozambique. Forest Ecology and Management. 2015;354:139-48. https://doi.org/10. 1016/j.foreco.2015.06.027

106. Goïta K, Mouloungou J, Bénié GB. Estimation of aboveground biomass and carbon in a tropical rain forest in Gabon using remote sensing and GPS data. Geocarto International. 2017;34:243-59. https://doi.org/10.1080/10106049.2017.1386720.

107. Zhu J, Hu H, Tao S, Chi X, Li P, Jiang L, et al. Carbon stocks and changes of dead organic matter in China's forests. Nat Commun. 2017;8:151. https://doi.org/10.1038/s41467-017-00207-1.

108. Kumar P, Pandey PC, Singh BK, Katiyar S, Mandal VP, Rani M, et al. Estimation of accumulated soil organic carbon stock in tropical forest using geospatial strategy. The Egyptian Journal of Remote Sensing and Space Science. 2016;19:109-23. https:// doi.org/10.1016/j.ejrs.2015.12.003.
109. Heagney EC, Rose JM, Ardeshiri A, Kovač M. Optimising recreation services from protected areas - understanding the role of natural values, built infrastructure and contextual factors. Ecosystem Services. 2018;31:358-70. https://doi.org/10.1016/j. ecoser.2017.10.007.

110. Hegetschweiler KT, Plum C, Fischer C, Brändli U-B, Ginzler C, Hunziker M. Towards a comprehensive social and natural scientific forest-recreation monitoring instrument - a prototypical approach. Landscape and Urban Planning. 2017;167:84-97. https://doi.org/10.1016/j.landurbplan.2017.06.002.

111. Tessa Hegetschweiler K, Fischer C, Moretti M, Hunziker M. Integrating data from National Forest Inventories into sociocultural forest monitoring - a new approach. Scandinavian Journal of Forest Research. 2020;35:274-85. https://doi.org/10. 1080/02827581.2020.1799066

112. Schmitt M. Potential of large-scale inland water body mapping from Sentinel-1/2 data on the example of Bavaria's lakes and rivers. PFG. 2020;46:217-89. https://doi.org/10.1007/s41064020-00111-2.

113. Fehrmann L, Gregoire TG, Kleinn C. Triangulation based inclusion probabilities: a design-unbiased sampling approach. Environ Ecol Stat. 2012;19:107-23. https://doi.org/10.1007/s10651-0110177-9.

114. Roth A, Kennel E, Knoke T, Matthes U. Die Linien-IntersektStichprobe: Ein effizientes Verfahren zur Erfassung von liegendem Totholz? Forstwissenschaftliches Centralblatt. 2003;122:318-36. https://doi.org/10.1007/s10342-003-0001-7.

115. van Laar A. sampling proportional to size with Bitterlich's mirror relascope. South African Forestry Journal. 2010;128:15-21. https://doi.org/10.1080/00382167.1984.9628920.

116. Woodall CW, Monleon VJ, Fraver S, Russell MB, Hatfield MH, Campbell JL, et al. The downed and dead wood inventory of forests in the United States. Sci Data. 2019;6:180303. https://doi. org/10.1038/sdata.2018.303.

117. Polewski P, Yao W, Heurich M, Krzystek P, Stilla U. Detection of fallen trees in ALS point clouds using a normalized cut approach trained by simulation. ISPRS Journal of Photogrammetry and Remote Sensing. 2015;105:252-71. https://doi.org/10.1016/j. isprsjprs.2015.01.010.

118. Polewski P, Yao W, Heurich M, Krzystek P, Stilla U. Learning a constrained conditional random field for enhanced segmentation of fallen trees in ALS point clouds. ISPRS Journal of Photogrammetry and Remote Sensing. 2018;140:33-44. https:// doi.org/10.1016/j.isprsjprs.2017.04.001.

119. Steinhardt U, Herzog F, Lausch A, Müller E, Lehmann S. Hemeroby index for landscape monitoring and evaluation. In: Lenz R, Hyatt DE, Pykh IA, editors. International conference on environmental indices systems analysis approach. Oxford: EOLSS; 1999. p. 237-54.

120. Holmgren J, Persson Å, Söderman U. Species identification of individual trees by combining high resolution LiDAR data with multi-spectral images. International Journal of Remote Sensing. 2008;29:1537-52. https://doi.org/10.1080/01431160701736471.

121. Dalponte M, Orka HO, Gobakken T, Gianelle D, Naesset E. Tree species classification in boreal forests with hyperspectral data. IEEE Trans. Geosci. Remote Sensing. 2013;51:2632-45. https:// doi.org/10.1109/TGRS.2012.2216272.

122. Vauhkonen J, Korpela I, Maltamo M, Tokola T. Imputation of single-tree attributes using airborne laser scanning-based height, intensity, and alpha shape metrics. Remote Sensing of Environment. 2010;114:1263-76. https://doi.org/10.1016/j.rse. 2010.01.016.

123. Braga G Jr, Peripato V, Dalagnol R, Ferreira MP, Tarabalka Y, O. $\mathrm{C}$, et al. Tree crown delineation algorithm based on a convolutional neural network. Remote Sensing. 2020;12:1288. https://doi.org/10.3390/rs12081288. 
124. Schmidhuber J. Deep learning in neural networks: An overview. Neural Netw. 2015;61:85-117. https://doi.org/10.1016/j.neunet. 2014.09.003.

125. Senf C, Pflugmacher D, Heurich M, Krueger T. A Bayesian hierarchical model for estimating spatial and temporal variation in vegetation phenology from Landsat time series. Remote Sensing of Environment. 2017;194:155-60. https://doi.org/10.1016/j.rse. 2017.03.020.

126. Stoffels J, Hill J, Sachtleber T, Mader S, Buddenbaum H, Stern O, et al. Satellite-based derivation of high-resolution forest information layers for operational forest management. Forests. 2015;6: 1982-2013. https://doi.org/10.3390/f6061982.

127. Meiforth JJ, Buddenbaum H, Hill J, Shepherd J. Monitoring of canopy stress symptoms in New Zealand Kauri trees analysed with AISA hyperspectral data. Remote Sensing. 2020;12:926. https://doi.org/10.3390/rs12060926.

128. Lee J, Yoon TK, Han S, Kim S, Yi MJ, Park GS, et al. Estimating the carbon dynamics of South Korean forests from 1954 to 2012. Biogeosciences. 2014;11:4637-50. https://doi.org/10.5194/bg11-4637-2014.

129. Rasel SMM, Groen TA, Hussin YA, Diti IJ. Proxies for soil organic carbon derived from remote sensing. International Journal of Applied Earth Observation and Geoinformation. 2017;59:157-66. https://doi.org/10.1016/j.jag.2017.03.004.

130. Lakyda P, Shvidenko A, Bilous A, Myroniuk V, Matsala M, Zibtsev S, et al. Impact of disturbances on the carbon cycle of forest ecosystems in Ukrainian Polissya. Forests. 2019;10:337. https://doi.org/10.3390/f10040337.

131. Wallner A, Elatawneh A, Schneider T, Knoke T. Estimation of forest structural information using RapidEye satellite data. Forestry. 2015;88:96-107. https://doi.org/10.1093/forestry/ cpu032.

132. Almulqu AA. Dynamic growth model simulation for carbon stock management in dry forest. Biosys. divers. 2017;25:249-54. https://doi.org/10.15421/011738.

133. Knoke T. Uncertainties and REDD+: implications of applying the conservativeness principle to carbon stock estimates. Climatic Change. 2013;119:261-7. https://doi.org/10.1007/s10584-0120662-7.

134. Atkinson MA, Edwards DM, Jensen FS, van der Jagt APN, Ditchburn BR, Sievänen T, et al. Harmonising, improving and using social and recreational data in National Forest Inventories across Europe. Annals of Forest Science. 2020;77:258. https://doi. org/10.1007/s13595-020-00952-2.

135. Kangas, Räty, Korhonen, Vauhkonen, Packalen. Catering information needs from global to local scales - potential and challenges with national forest inventories. Forests. 2019;10:800. https://doi. org/10.3390/f10090800.

136. Durante P, Martín-Alcón S, Gil-Tena A, Algeet N, Tomé J, Recuero $\mathrm{L}$, et al. Improving aboveground forest biomass maps: from high-resolution to national scale. Remote Sensing. 2019;11: 795. https://doi.org/10.3390/rs11070795.

137.• Næsset E, Ørka HO, Solberg S, Bollandsås OM, Hansen EH, Mauya E, et al. Mapping and estimating forest area and aboveground biomass in miombo woodlands in Tanzania using data from airborne laser scanning, TanDEM-X, RapidEye, and global forest maps: A comparison of estimated precision. Remote Sensing of Environment. 2016;175:282-300. https://doi.org/10. 1016/j.rse.2016.01.006 Excellent case study showing how auxiliary information may enhance the precision of terrestrial sampling tremendously.

138. Duncanson L, Neuenschwander A, Hancock S, Thomas N, Fatoyinbo T, Simard M, et al. Biomass estimation from simulated GEDI, ICESat-2 and NISAR across environmental gradients in Sonoma County. California. Remote Sensing of Environment. 2020;242:111779. https://doi.org/10.1016/j.rse.2020.111779.
139. Köhl M, Neupane PR, Mundhenk P. REDD+ measurement, reporting and verification - A cost trap? Implications for financing REDD+MRV costs by result-based payments. Ecological Economics. 2020;168:106513. https://doi.org/10.1016/j. ecolecon.2019.106513.

140. Plugge D, Köhl M. Estimating carbon emissions from forest degradation: implications of uncertainties and area sizes for a REDD+ MRV system. Can. J. For. Res. 2012;42:1996-2010. https://doi. org/10.1139/X2012-129.

141. Grussu G, Testolin R, Saulei S, Farcomeni A, Yosi CK, de Sanctis $\mathrm{M}$, et al. Optimum plot and sample sizes for carbon stock and biodiversity estimation in the lowland tropical forests of Papua New Guinea. Forestry. 2016;89:150-8. https://doi.org/10.1093/ forestry/cpv047.

142. Kleinn C, Ståhl G, Fehrmann L, Kangas A. Issues in forest inventories as an input to planning and decision processes. Allgemeine Forst- und Jagdzeitung. 2010;181:205-10.

143. Burkhard B, editor. Mapping ecosystem services. Sofia: Pensoft; 2017.

144. Maes J, Fabrega N, Zulian G, Barbosa A, Vizcaino P, Ivits E, et al. Mapping and assessment of ecosystems and their services: trends in ecosystems and ecosystem services in the European Union between 2000 and 2010. Luxembourg: Publications Office. 2015.

145. García-Nieto AP, García-Llorente M, Iniesta-Arandia I, MartínLópez B. Mapping forest ecosystem services: from providing units to beneficiaries. Ecosystem Services. 2013;4:126-38. https://doi. org/10.1016/j.ecoser.2013.03.003.

146. Maes J, Crossman ND, Burkhard B. Mapping ecosystem services. In: Potschin M, Haines-Young RH, Fish R, Turner RK, editors. Routledge handbook of ecosystem services. London, New York: Routledge, Taylor \& Francis Group; 2016. p. 188-204.

147. Weibel B, Rabe S-E, Burkhard B, Grêt-Regamey A. On the importance of a broad stakeholder network for developing a credible, salient and legitimate tiered approach for assessing ecosystem services. OE. 2018;3:e25470. https://doi.org/10.3897/oneeco.3. e25470.

148. Kokkoris IP, Bekri ES, Skuras D, Vlami V, Zogaris S, Maroulis G, et al. Integrating MAES implementation into protected area management under climate change: a fine-scale application in Greece. Sci Total Environ. 2019;695:133530. https://doi.org/10.1016/j. scitotenv.2019.07.336.

149. Naidoo R, Balmford A, Costanza R, Fisher B, Green RE, Lehner $\mathrm{B}$, et al. Global mapping of ecosystem services and conservation priorities. Proc Natl Acad Sci U S A. 2008;105:9495-500. https:// doi.org/10.1073/pnas.0707823105.

150. Burkhard B, Kroll F, Müller F, Windhorst W. Landscapes' capacities to provide ecosystem services - a concept for land-cover based assessments. LO. 2009;15:1-22. https://doi.org/10.3097/ LO.200915.

151. Burkhard B, Kroll F, Nedkov S, Müller F. Mapping ecosystem service supply, demand and budgets. Ecological Indicators. 2012;21:17-29. https://doi.org/10.1016/j.ecolind.2011.06.019.

152. Feranec J. European landscape dynamics: CORINE land cover data. Boca Raton, FL: CRC Press; 2016.

153. Hollmann R, Merchant CJ, Saunders R, Downy C, Buchwitz M, Cazenave A, et al. The ESA climate change initiative: satellite data records for essential climate variables. Bull. Amer. Meteor. Soc. 2013;94:1541-52. https://doi.org/10.1175/BAMS-D-11-00254.1.

154. Baranzelli C, Batista e silva F, Diogo V, Jacobs-Crisioni C, Kavalov B, Lavalle C, et al. The LUISA territorial reference scenario 2017: a technical description. Luxembourg: Publications Office of the European Union; 2017.

155. European statisticians. The Lucas survey: European statisticians monitor territory. Updated edition - June 2003. Luxembourg: Publications Office; 2003. 
156. Leckie DG, Gillis MD. Forest inventory in Canada with emphasis on map production. The Forestry Chronicle. 1995;71:74-88. https://doi.org/10.5558/tfc71074-1.

157. Bae S, Levick SR, Heidrich L, Magdon P, Leutner BF, Wöllauer $\mathrm{S}$, et al. Radar vision in the mapping of forest biodiversity from space. Nat Commun. 2019;10:4757. https://doi.org/10.1038/ s41467-019-12737-x.

158. Asner GP, Martin RE, Knapp DE, Tupayachi R, Anderson CB, Sinca F, et al. Airborne laser-guided imaging spectroscopy to map forest trait diversity and guide conservation. Science. 2017;355: 385-9. https://doi.org/10.1126/science.aaj1987.

159. Asner GP. Tropical forest carbon assessment: integrating satellite and airborne mapping approaches. Environ. Res. Lett. 2009;4: 34009. https://doi.org/10.1088/1748-9326/4/3/034009.

160. Pukall K. Mögliche Entwicklungslinien für das Bundeswaldgesetz. NuR. 2014;36:171-6. https://doi.org/10. 1007/s10357-014-2608-5.

161. Tiemann A, Ring I. Challenges and opportunities of aligning forest function mapping and the ecosystem service concept in Germany. Forests. 2018;9:691. https://doi.org/10.3390/19110691.

162. Englund O, Berndes G, Cederberg C. How to analyse ecosystem services in landscapes - a systematic review. Ecological Indicators. 2017;73:492-504. https://doi.org/10.1016/j.ecolind. 2016.10.009.

163.• Termansen M, McClean CJ, Jensen FS. Modelling and mapping spatial heterogeneity in forest recreation services. Ecological Economics. 2013;92:48-57. https://doi.org/10.1016/j.ecolecon. 2013.05.001 Excellent study on choice modelling that incorporates inventory information.

164. Watson KB, Galford GL, Sonter LJ, Koh I, Ricketts TH. Effects of human demand on conservation planning for biodiversity and ecosystem services. Conserv Biol. 2019;33:942-52. https://doi. org/10.1111/cobi.13276.

165. Zhao C, Sander HA. Quantifying and mapping the supply of and demand for carbon storage and sequestration service from urban trees. PLoS ONE. 2015;10:e0136392. https://doi.org/10.1371/ journal.pone.0136392.

166. Costanza R, d'Arge R, de Groot R, Farber S, Grasso M, Hannon $\mathrm{B}$, et al. The value of the world's ecosystem services and natural capital. Nature. 1997;387:253-60. https://doi.org/10.1038/ $387253 \mathrm{a} 0$.

167. Costanza R, de Groot R, Sutton P, van der Ploeg S, Anderson SJ, Kubiszewski I, et al. Changes in the global value of ecosystem services. Global Environmental Change. 2014;26:152-8. https:// doi.org/10.1016/j.gloenvcha.2014.04.002.

168. de Groot R, Brander L, van der Ploeg S, Costanza R, Bernard F, Braat L, et al. Global estimates of the value of ecosystems and their services in monetary units. Ecosystem Services. 2012;1:50 61. https://doi.org/10.1016/j.ecoser.2012.07.005.

169. Frélichová J, Vačkáŕ D, Pártl A, Loučková B, Harmáčková ZV, Lorencová E. Integrated assessment of ecosystem services in the Czech Republic. Ecosystem Services. 2014;8:110-7. https://doi. org/10.1016/j.ecoser.2014.03.001.

170. Kindu M, Schneider T, Teketay D, Knoke T. Changes of ecosystem service values in response to land use/land cover dynamics in Munessa-Shashemene landscape of the Ethiopian highlands. Sci Total Environ. 2016;547:137-47. https://doi.org/10.1016/j. scitotenv.2015.12.127.

171. Kreuter UP, Harris HG, Matlock MD, Lacey RE. Change in ecosystem service values in the San Antonio area. Texas. Ecological Economics. 2001;39:333-46. https://doi.org/10.1016/S09218009(01)00250-6.
172. Kubiszewski I, Costanza R, Dorji L, Thoennes P, Tshering K. An initial estimate of the value of ecosystem services in Bhutan. Ecosystem Services. 2013;3:e11-21. https://doi.org/10.1016/j. ecoser.2012.11.004

173. Kubiszewski I, Costanza R, Anderson S, Sutton P. The future value of ecosystem services: global scenarios and national implications. Ecosystem Services. 2017;26:289-301. https://doi.org/ 10.1016/j.ecoser.2017.05.004.

174. Czajkowski M, Ahtiainen H, Artell J, Meyerhoff J. Choosing a functional form for an international benefit transfer: evidence from a nine-country valuation experiment. Ecological Economics. 2017;134:104-13. https://doi.org/10.1016/j.ecolecon.2017.01. 005.

175. Nordhaus WD. Revisiting the social cost of carbon. Proc Natl Acad Sci U S A. 2017;114:1518-23. https://doi.org/10.1073/ pnas. 1609244114

176. Knoke T, Paul C, Rammig A, Gosling E, Hildebrandt P, Härtl F, et al. Accounting for multiple ecosystem services in a simulation of land-use decisions: does it reduce tropical deforestation? Glob Chang Biol. 2020;26:2403-20. https://doi.org/10.1111/gcb. 15003 .

177. Knoke T, Kindu M, Jarisch I, Gosling E, Friedrich S, Bödeker K, et al. How considering multiple criteria, uncertainty scenarios and biological interactions may influence the optimal silvicultural strategy for a mixed forest. Forest Policy and Economics. 2020;118:102239. https://doi.org/10.1016/j.forpol.2020.102239.

178. Kangas AS, Horne P, Leskinen P. Measuring the value of information in multicriteria decisionmaking. Forest Science. 2010;56: 558-66.

179. Kangas A, Gobakken T, Puliti S, Hauglin M, Naesset E. Value of airborne laser scanning and digital aerial photogrammetry data in forest decision making. Silva Fenn. 2018;52. https://doi.org/10. 14214/sf.9923.

180. Kangas AS. Value of forest information. Eur J Forest Res. 2010;129:863-74. https://doi.org/10.1007/s10342-009-0281-7.

181.• Kangas A, Korhonen KT, Packalen T, Vauhkonen J. Sources and types of uncertainties in the information on forest-related ecosystem services. Forest Ecology and Management. 2018;427:7-16. https://doi.org/10.1016/j.foreco.2018.05.056 Comprehensive overview over ES indicators and common uncertainties.

182. Knoke T, Weber M. Expanding carbon stocks in existing forests a methodological approach for cost appraisal at the enterprise level. Mitig Adapt Strateg Glob Change. 2006;11:579-605. https:// doi.org/10.1007/s11027-006-1051-1.

183. Grassi G, Federici S, Achard F. Implementing conservativeness in REDD+ is realistic and useful to address the most uncertain estimates. Climatic Change. 2013;119:269-75. https://doi.org/10. 1007/s10584-013-0780-x.

184. Wallner A, Elatawneh A, Schneider T, Kindu M, Ossig B, Knoke T. Remotely sensed data controlled forest inventory concept. Eur J Remote Sens. 2017;51:75-87. https://doi.org/10.1080/22797254. 2017.1403295.

185. Birchler UW, Bütler M. Information economics. 1st publ. 2007, reprinted. London: Routledge; 2008.

186. Woudenberg SW, Conkling BL, O’Connell BM, LaPoint EB, Turner JA, Waddell KL. The Forest Inventory and Analysis Database: database description and users manual version 4.0 for Phase 2. Ft. Collins, CO: U.S. Department of Agriculture, Forest Service, Rocky Mountain Research Station; 2010.

Publisher's Note Springer Nature remains neutral with regard to jurisdictional claims in published maps and institutional affiliations. 